Şırnak Üniversitesi

Ilahiyat Fakültesi Dergisi

Cilt: 11, Sayı: 25, Aralık 2020

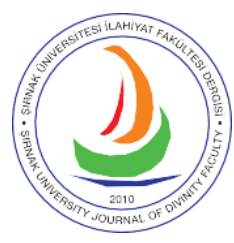

e-ISSN 2667-6575
Şrnak University

Journal of Divinity Faculty

Volume: 11, Issue: 25, December 2020

\title{
Cumhuriyet Dönemi Dinler Tarihi Çalışmalarında Antropolojik Bakış Açısı
}

Anthropological Perspective on the History of Religions Studies in the Republican Period

\section{İsmet TUNC}

Dr. Öğr. Üyesi, Şırnak Üniversitesi, İlahiyat Fakültesi, Dinler Tarihi Ana Bilim Dalı Assistant Professor, Şırnak University, Faculty of Divinity, Department of History of Religions

Şırnak, Turkey

tuncismet@gmail.com

https://orcid.org/0000-0002-4767-8412

\section{Ali Osman KURT}

Prof. Dr., Ankara Sosyal Bilimler Üniversitesi, İslami İlimler Fakültesi, Dinler Tarihi Ana Bilim Dalı Professor, Social Sciences University of Ankara, Faculty of Islamic Studies, Department of History of Religions Ankara, Turkey

aliosman.kurt@asbu.edu.tr https://orcid.org/0000-0003-1459-7832

\section{Makale Bilgisi / Article Information}

Makale Türü / Article Types: Araştırma Makalesi / Research Article

Geliş Tarihi / Received: 25 Eylül / September 2020

Kabul Tarihi / Accepted: 3 Aralık / December 2020

Yayın Tarihi / Published: 15 Aralık / December 2020

Cilt / Volume: 11 Sayı / Issue: 25 Sayfa / Pages: 628-656

Atıf / Cite as: Tunç, İsmet - Kurt, Ali Osman. "Cumhuriyet Dönemi Dinler Tarihi Çalışmalarında Antropolojik Bakış Açısı" [Anthropological Perspective on the History of Religions Studies in the Republican Period]". Şırnak Üniversitesi İlahiyat Fakültesi Dergisi - Şırnak University Journal of Divinity Faculty 11/25 (December 2020), 628-656. https://doi.org/10.35415/sirnakifd.800203

Etik Beyanı / Ethics Declaration: Bu makalede bilimsel araştırma ve yayın etiği ilkelerine riayet edilmiştir. Makale etik izin gerektirmeyen bir çalışma olup en az iki hakem tarafından incelenmiş ve intihal içermediği teyit edilmiştir. / In this article, the principles of scientific research and publication ethics are respected. The article is a study that does not require ethical permission. It has been reviewed by at least two referees and was confirmed that it did not contain plagiarism.

Copyright (C Published by Şırnak Üniversitesi, İlahiyat Fakültesi / Şırnak, Türkiye (Şırnak University, Faculty of Divinity, Şırnak, 73000 Turkey). 


\section{Öz}

Türkiye'de dinler tarihinin geçmişi oldukça yakın bir zamana tekabül etmektedir. Cumhuriyetin kuruluş yıllarında din, üzerinde en fazla durulan konuların başında gelmektedir. Din üzerine tartışmalar daha çok din-devlet ilişkisi ve bunun toplum üzerindeki etkisi ile alakalı olmuştur. Konuyla ilgili çeşitli görüş ve değerlendirmeler bulunmakla birlikte dinin toplumsal bir gereklilik olduğu düşüncesi kabul görmüş ve bunun yasal zemine oturtulması yönünde bazı çalışmalar yapılmıştır. Bu kapsamda din eğitimi milliyetçilik ekseninde gelişen bir seyir izlemiştir. Dinler tarihi de bu seyrin bir parçası olarak kendine has bir yol çizmiştir. Bu çalışmada Türkiye' de dinler tarihine kaynaklık eden çalışmalar ve dinler tarihi çalışmaları ile antropoloji arasındaki ilişki incelenmiştir. İlahiyat alanında ön plana çıkan dinler tarihi ile seküler bir bilim olarak bilinen antropoloji ilişkisinin Cumhuriyetin ilk yıllarında yapılan kültürel ve dinî olguların tespitine yönelik çalışmalara yansıması ele alınmıştır. Bu bağlamda, çalışmada öncelikle antropolojinin Türkiye' deki görünürlüğü ve ulus devlet inşasındaki rolünün anlaşılması önem arz etmektedir. Din üzerine yapılan tartışma ve araştırmalar ile Anadolu coğrafyasından elde edilen etnografik verilerin dinler tarihi çalışmalarındaki yansımaları ve Türkiye'de dinler tarihçiliğinin başlangıç itibariyle hangi temel ilkelere dayandığını ortaya koymak amaçlanmıştır. Bu çalışma Cumhuriyet dönemi dinler tarihçiliği ile ilgili sınırlı sayıdaki şahsiyetler ve eserleri özelinde işlenmiştir.

Anahtar Kelimeler: Dinler Tarihi, Antropoloji, Etnografya, Türk Dini Tarihi, Hikmet Tanyu.

\section{Abstract}

The studies on the history of religions in Turkey are fairly new. During the foundation years of the Republic, religion was one of the most emphasized subjects in general. The debates on religion have mostly been about the religion-state relationship and its impact on society. Although there are various opinions and evaluations on the subject, the idea that religion is a social necessity has been accepted and some studies have been done to put it on a legal basis. In this context, religious education followed a course that developed in the axis of nationalism. History of religions has also made its own path as a part of this course. In this study, the relationship between anthropology and the studies of the history of religions and their sources in Turkey are examined. The reflection of the relationship between the history of religions, which come to the fore in the field of theology, and anthropology, which is known as a secular science, on studies conducted to determine the cultural and religious phenomena in the first years of the Republic are discussed. In this context, it is important to understand the first occurrence of anthropology in Turkey and its role in building a nation-state. This study aims to reveal the reflections of the discussions and research made on religion and ethnographic data on the history of religions, obtained from Anatolia, and basic principles of the beginning of religious historiography in Turkey. This study is focused on a limited number of personalities and their works on the history of religion in the Republican period.

Keywords: History of Religions, Anthropology, Ethnography, Turkish Religious History, Hikmet Tanyu. 


\section{Extended Abstract}

In the first studies on the history of religions in Turkey, researchers have largely benefited from the data provided by anthropology. The positivist understanding seems to be dominant in most of the early anthropology studies. In this context, this study draws attention to the extent of effectiveness of the anthropological perspective of the history of Religions studies conducted in the first years of the Republic of Turkey. At the same time, it is seen that studies on the history of religions, along with other fields, use this perspective in the process of building a nation-state. The study includes an assessment of a limited number of works carried out in the scope of the history of religions in the first years of the Republic of Turkey.

The history of religions studies in Turkey have been introduced in the late Ottoman period. As a result of the relations of the Ottoman Empire's intellectual class with Europe, various issues about human history have begun to be discussed in society. In time, works that will be counted as the first religious history studies were written. These were mostly done by those who were aware of the history of religions in the West. The methods and techniques used in scientific research were ignored in these studies. However, it is seen that more systematic and scientific studies were carried out after the establishment of the Republic. Studies on various traditional religions have emerged as a part of the history of religions classes. Likewise, religions belonging to certain regions are seen to be the subject of books. These studies are written from an anthropological point of view, especially just as in the west.

With the establishment of the Republic, various investigations were launched regarding Turkish culture and its source. The findings regarding Turkish culture in a wide geography from Central Asia to the prehistoric periods of Anatolia have been examined and various theories have been put forward. Especially, it has been suggested that Turks have an older history than many nations. During this period, thinkers such as Yusuf Akçura and Ziya Gökalp frequently wrote articles on Turkishness and made a description of an ideal society. In this process, religion is one of the most important topics of discussion. Various discussions have been made about the place of religion in the new state system. In this process, efforts were made to help the history of religions gain an institutional identity as a scientific discipline. Studies on religious issues have been carried out in parallel or intertwined with studies on the history of Turks. Therefore, anthropology and anthropological perspective have been visible in the history of religions as well as in other fields. Some religious history studies in this period support the process of building a nation-state. For example, historians of religions such as Ömer Hilmi Budda have preferred to express their thoughts in the field of religion through Turkishness. According to this, Turks have been the source of many civilizations in the past. These thoughts have been kept on the agenda with state-sponsored projects such as the Sun Language Theory and the Turkish History Thesis. Şemseddin Günaltay carried out important studies on the beliefs of the Turks before they converted to Islam. He tried to explain the old beliefs of Arabs using mostly anthropological data. After Günaltay, Georges Dumézil, an important person in making the history of religions a scientific discipline in Turkey, has come to the fore. He interpreted the history of religions with anthropological data and made the Circassians and their subgroups a study subject. Therefore, anthropology is widely seen in Dumézil's works. Subsequently, with Annemarie Schimmel and Hikmet Tanyu, who was trained by him, the history of religions became institutionalized by scientific and systematic studies. Tanyu skillfully used ethnographic data in his works. He benefited from the works of ethnologists and anthropologists of the period and made similar studies by considering religious culture. In this context, Tanyu interpreted a phenomenon not only in terms of the history of religions but also in terms of ethnography and anthropology. Tanyu established the connection of the culture he was in with the past and integrated the 
religion of Islam and national feelings in the same works. This method has led to the formation of a school on Turkish Religious History. Turkish Religious studies carried out today continue in this direction. 


\section{Giriş $^{1}$}

Osmanlı Devleti'nin son dönemlerinde Avrupa'dan neden geri kalındığı üzerine çeşitli tartışmalar yapılmıştır. Eğitim almak için Avrupa'ya gönderilen ya da sürgün edilen iyi eğitimli Osmanlı aydınları, Avrupa'nın sanayileştiği bir dönemde geri kalmışlığın nedenini Osmanlı'nın teokratik düzene sahip olmasına bağlamışlardır. ${ }^{2} \mathrm{Bu}$ aydınlar devletin mevcut idare şeklini bir sorun olarak görmüş, bunun esnetilmesini ya da değişmesini talep etmişlerdir. Avrupa'da antropoloji biliminin, dinî görüş ve eylemlerin dışında bir düşünce biçimi olarak ortaya çıkması, Osmanlı aydınının da dikkatini çekmiştir. Sosyal Darwinist düşünce, biyolojik evrim odaklı tartışmaların başladığı dönemden II. Meşrutiyet'in ilanına kadar aydın sınıfı arasında tartışıldığı halde, geniş toplum kesiminde açıkça gündem olmamıştır. Dolayısıyla bu düşüncenin aydın sınıfı arasında da olsa Batı ile eş zamanlı olarak Osmanlı'da da başladığı anlaşılmaktadır. ${ }^{3}$

Türkiye, örnek aldığı Batı toplumlarında olduğu gibi yeni bir düzen için laiklik ilkesini benimsemiştir. Türkiye' de laiklik düşüncesi Osmanlı'nın son dönemlerinde yeni arayışlara yönelen İttihat ve Terakki kadrolarınca bir çözüm olarak sunulmuştur.4 Türkçülügüün iyi bir seçenek olarak görülmesinde Osmanlı'nın güçlü oluşundan memnun olmayan Avrupalıların Türkler hakkındaki olumsuz kanaatleri etkili olmuştur. Osmanlı aydınlarının yaptığı araştırmalar Türklerin köklü bir geçmişe sahip olduklarını göstermekteydi. Yine, geçmişte Osmanlı topraklarını gezen ve şahit oldukları iyi izlenimleri yazan gezginlerin yazdıkları da Osmanlı aydının ilgisini çekmiştir. Bunun yanında İslam öncesi dönemde Türklerin oldukça köklü bir medeniyete sahip olduklarına dair yazılanlar da aydın kesiminin geçmişe olan ilgisini arttırmıştır. Bu yönde birçok önemli çalışmada, Osmanlı Türklerinin haricinde etnik olarak Türk olan diğer Asya halklarından da övgüyle bahsedilmiştir. ${ }^{5}$

Ziya Gökalp'e göre Türkçülük, Anadolu'da ortaya çıkmadan önce Avrupa'da, ilkin Türk ürünlerine duyulan ilgiyle, ikincisi ise Türkoloji çalışmalarıyla bilinmekteydi. Böylece

1 Bu çalışma “Türkiye' de Dinler Tarihi Çalışmalarında Antropolojinin Etkisi” başlıklı doktora tezi esas alınarak hazırlanmıştır. / This article is extracted from doctorate dissertation entitled "The Impact of Anthropology on the Studies of History of Religions in Turkey" (PhD Dissertation, Ankara Yıldırım Beyazıt University, Ankara/Turkey, 2019).

2 Dönemin düşünce biçimi ve yapısı hakkında ayrıntılar için bk. Feroz Ahmad, Modern Türkiye'nin Oluşumu, çev. Yavuz Alogan (İstanbul: Sarmal Yayınevi, 1994); Gotthard Jaschke, Yeni Türkiye’de İslamlık, çev. Hayrullah Örs (Ankara: Bilgi Yayınevi, 1972); Niyazi Berkes, Türkiye'de Çağdaşlaşma (İstanbul: Yapı Kredi Yayınları, 2016).

3 Atila Doğan, Osmanlı Aydınları ve Sosyal Darwinizm (İstanbul: İstanbul Bilgi Üniversitesi Yayınları, 2006), 3.

4 Mohammed Arkoun, "İslâmi Bir Bakış Açısı İçinde Pozitivizm ve Gelenek, Kemalizm Olayı", Cogito 1 (1994), 57.

5 David Kushner, Türk Milliyetçiliğinin Doğuşu (1876-1908), çev. Şevket Serdar Türet vd. (İstanbul: Kervan Yayınları, 1979), 12-13. 
Orta Asya'da görülen Türk kültürünün geçmişe uzanan izlerini görmek mümkün olmuştur. Gökalp, Türklerin yüksek medeniyet inşa ettiklerini ve sahip oldukları geçmişin aydınların ruhlarını etkisi altına aldığını ifade etmektedir. ${ }^{6}$ Avrupa'da olduğu gibi çok uluslu imparatorlukların yerine kurulan devletler gibi Türkiye Cumhuriyeti de belli bir etnisiteye dayandırılarak kurulmuştur. Böylece Türkçülük düşüncesinin kültürel boyuttan politik boyuta aktarılması milliyetçi tezler öne süren Ziya Gökalp (1876-1924) ve Yusuf Akçura (18761935) gibi aydınların görüşleri çerçevesinde şekillenmiştir. İleride oluşturulması düşünülen ideal toplum tipi olarak milliyetçi ve aynı zamanda pozitivist anlayışın hâkim olduğu, dinin daha çok insan için içsel bir ihtiyaç olarak algılandığı, ibadetin anlaşılabilmesi için Türkçe yapılması gibi çözüm önerileri dile getirilmiştir.7 Yusuf Akçura, Üç Tarz-ı Siyaset isimli makalesinde, Türklük dışında Osmanlı topraklarının bir arada tutulmasının imkânsız olduğunu ileri sürmüştür. Ona göre ırk üzerinden birleşmek, din üzerinden birleşmeye oranla daha olanaklıdır. ${ }^{8}$ Akçura, kültürel, tarihî ve dil bakımından Türklerin bir olmasına vurgu yapmıştır. Onun ırk tanımında fiziksel ve biyolojik unsurlardan ziyade, antropolojik çalışmaların vurguladığı ortak kültürel miras ve aynı siyasal tercihleri paylaşma gereğinin duyulmadığı budun ${ }^{9}$ kavramı ön plana çıkmıştır. ${ }^{10}$

Çoğunluğu pozitivist düşüncede olan modernist, Osmanlıcı, İslamcı olan Jön Türkler tarafından sürdürülen din, iman, etnik kimlik gibi kavramlar üzerinden tartışmalardan ilk olarak Ziya Gökalp kendini ayrı bir yere konumlandırmıştır. O hem Türkçülüğü hem de medeniyeti imanın dayanağı kabul ederek Türklüğü Türkçülüğe dönüştürme yoluna gitmiştir. Böylece, medeniyet tıpkı bir din gibi görülmüş ve ona gönülden güvenmek ve inanmak gerektiği savunulmuştur. Gökalp medeniyet ve milli kimliği bölünmez bir bütün olarak düşünmüştür. Dolayısıyla Avrupa ile birleşmek ve milli kimliği muhafaza etmek için "dini inanç" yerine "milli ve modernist inanç" modelinin benimsenmesini gerekli görmüştür. ${ }^{11}$ Gökalp, Batı medeniyetine girmekle ne Türklükten ne de Müslümanlıktan bir şey

6 Ziya Gökalp, Türkçülü̆̆̈̈n Esasları (İstanbul: Varlık Yayınları, 1969), 7-8.

7 Konu hakkında o dönemin Türkçe ibadet ve uygulamalardaki örnekler için bk. Dücane Cündioğlu, Türkçe Kur'an ve Cumhuriyet İdeolojisi (İstanbul: Kitabevi, 1998); Jaschke, Yeni Türkiye'de İslamlik.

8 Yusuf Akçura, Üç Tarz-ı Siyaset (Ankara: Türk Tarih Kurumu Basımevi, 1976), 33-35.

9 Aralarında dil, kültür ve soyca bir bağ olan toplulukları ifade eder. Ulus, millet anlamına gelir. Türkçe literatürde ırkiyat ve halkbilim olarak da kullanılır. TDK, “budun”, Türkçe Sözlük, 10. Baskı (Ankara, Türk Dil Kurumu Yayınları: 2005), 318.

10 François Georgeon, Türk Milliyetçiliğinin Kökenleri Yusuf Akçura (1876-1935), çev. Alev Er (İstanbul: Tarih Vakfı Yurt Yayınları, 2005), 43-44.

11 Kemal H. Karpat, İslâm'ın Siyasallaşması. Osmanlı Devleti'nin Son Döneminde Kimlik, Devlet, İnanç ve Cemaatin Yeniden Yapılandırılması, çev. Şiar Yalçın (İstanbul: Timaş Yayınları, 2013), 600-601. 
kaybedilebileceğini ifade ederek, medeniyet değiştirmenin din değiştirmek anlamına gelmediğini ifade etmiştir. ${ }^{12}$ Gökalp, cumhuriyetin temel politikalarının oluşmasında en belirleyici kişilerden biri olduğu gibi görüşleri Mustafa Kemal üzerinde etkili olmuştur. ${ }^{13}$

Cumhuriyetin kurulma aşamasında, dini söylemin ötesinde bilimin ön ayak olduğu ve kültürün dini boyutunun da ihmal edilmediği millî bir kimlik inşası sağlanmaya çalışılmıştır. Antropoloji bilimi ulus devlet sürecinde devletin temel politikaları doğrultusunda yapılan çalışmalarda etkin biçimde kullanılmıştır. Antropolojik bakış açısı hem milli kimliğin inşasındaki verileri sağlama hem de bunların kültürel alandaki yansımalarını yorumlamada kullanılmıştır. Çünkü Avrupa'da bu yönde belli ilerlemeler sağlanmıştır. Bu kapsamda Türkiye'de istenilen, bu yöntemin kullanılması ile belirlenen gelişmişlik ölçütlerini sağlamak ve bu yönde gelişme göstermektir. Dolayısıyla dinler tarihi alanındaki çalışmalarda da ulusa ve milli kültüre vurgu yapan bir bakış açısı ön planda tutulmuşumdan başarılan en öncelikli husus, Türk ulusunun, indekslerin tarif ettiği beyaz ırka eşit olduğunun kanıtlanmış olmasıydı. Bundan sonraki süreç bu anlayışın üzerine inşa edildiği için, bu konudaki her çaba kimliğin birliğini ve yüceliğini vurgulamak için yapılmıştır. ${ }^{14}$

\section{Cumhuriyet Dönemi Ulus Devlet İnşa Süreci: Din, Kültür ve Antropoloji}

Osmanlı Devleti'nden sonra kurulan Türkiye Cumhuriyeti'nde ulus devlet inşa sürecinde çeşitli çalışmalar yapılmıştır. Buna göre Türk milletinin ve Anadolu'da yaşamış geçmiş medeniyetlere ait ırksal özellikler ve dini inançların tespitine yönelik birtakım araştırmalara gidilmiştir. Bu yöndeki arayışların bir sonucu olarak kurulan Türk Antropoloji Enstitüsü'nün temel amacı, Türklerin diğer milletler arasındaki yerinin belirlenmesidir. ${ }^{15}$ Söz konusu çalışmalar için de bu alanda çalışacak kişiler Avrupa'ya gönderilerek, farklı ülkelerde antropoloji eğitimleri almaları sağlanmıştır. ${ }^{16}$

Fizik antropoloji yoğunluklu başlayan antropoloji enstitüsü çalışmaları, daha sonra Türk Tarih Kurumu'nun da aktif katılımıyla çeşitli bilimsel çalışmaların yapıldığı bir merkeze dönüştürülmüştür. Özellikle arkeolojik kazılar aracılığıyla Türklerin eski inançlarına yönelik

12 Erol Güngör, Kültür Değişmesi ve Milliyetçilik (İstanbul: Ötüken Neşriyat, 2006), 13.

13 Yahya Akyüz, Türk Eğitim Tarihi (İstanbul: Pegem Akedemi, 2011), 310.

14 Afet İnan, Atatürk Hakkında Hatıralar ve Belgeler, Arı İnan (ed.) (İstanbul: Türkiye İş Bankası Kültür Yayınları, 2009), 256. Afet İnan, Türkiye Halkının Antropolojik Karakteri ve Türkiye Tarihi (Ankara: Türk Tarih Kurumu Basımevi, 1947), 5.

15 Şevket Aziz Kansu, Türk Antropoloji Enstitüsü Tarihçesi (İstanbul: Maarif Matbaası, 1940), 1.

16 Remzi Demir-Doğan Atılgan, Dil ve Tarih-Coğrafya Fakültesi ve Türkiye'de Beşeri Bilimlerin Yeniden İnşaası (Ankara: Ankara Üniversitesi Basımevi, 2008), 37. 
çalışmalar yapılmıştır. Bu merkez Osmanlı Devleti'nin yerine kurulan Türkiye

Cumhuriyeti'nin uluslaşma çabalarını bilimsel açıdan destekleme görevi görmüştür. Yerli ve yabancı bilim kuruluşlarıyla ortak çalışmalar yapılmış, enstitünün "birinci ve öncelikli hedefi" Türklerin fiziki özelliklerinin belirlenmesi ve Batı toplumları tarafından belirlenen, toplumların gelişmişlik seviyesine göre oluşturulan sınıflamaya dahil olmak şeklinde belirlenmiştir. Bu bakımdan 1930'lu yıllar boyunca devam eden çalışmalar Türk Tarih Tezi ${ }^{17}$ ve Güneş Dil Teorisii gibi yeni uğraşlara yol açmış, devlet destekli 64.000 kişinin fizik antropoloji yöntemleriyle ölçüm yapılarak bilimsel bir çalışmaya tabi tutulmaları dünyada büyük yankı uyandırmıştır. Buna göre şüphesiz Anadolu insanı Avrupa insanından aşağı bir ırk değil, hatta o halklara kaynaklık ettiği için daha üstün konumda düşünülmüştür. ${ }^{19}$

Yeni ulus için gerekli olan bilimsel veriler ve var olan düşünsel ortam, hilafet ve saltanatın olmadığı, elde edilen başarıların geçmişle bağlantılı olarak sağlam dayanakları olan milli tarih anlayışına göre sürdürülmüştür. Bu durumda İslam öncesi geçmişe büyük ilgi gösterilmiş, bundan dolayı arkeolojik kazılara öncelik verilerek, tarih gittikçe uzak geçmişte aranmış ve tarih kitaplarındaki Nuh Peygamber'in mitolojik anlatımına dayanan söylenceler yerine antropoloji ve arkeolojinin bulguları daha uygun kabul edilmiştir. Bilimin mutlak kanıtlar üzerine kurulması ve gerektiğinde yanlışlanabilir olması düşüncesi hâkim bir anlayış olarak sürdürülmüştür. ${ }^{20}$ Böyle bir bilim anlayışı yeni kurulan cumhuriyetin vatandaşlarının

17 Sistematik Türkçülük çalışmaları sonucunda gelişen ve olgunlaşan, Cumhuriyet'in kuruluş yıllarında savunulan düşünceler bütünü. Bu dönem boyunca, Tarih Kongreleri, Dil kurultayları, Arkeoloji müzeleri, düzenli hâle getirilen çivi yazılı tablet koleksiyonlarıyla Anadolu'ya ait tarihsel ve kültürel geçmiş gün yüzüne çıarılmaya çalışılmıştır. Anadolu'daki en eski medeniyetlerin Orta Asya'dan gelen Türkler tarafından kurulduğunu savunan Türk Tarih Tezi bu çalışmalardaki temel teorik dayanaktır. Özellikle Sümer ve Hitit medeniyetlerine özel önem verilmiştir. Çünkü Anadolu coğrafyası ile Yakındoğu uygarlıkları arasında Türklerle en fazla benzerlik gösteren uygarlık Sümer ve Hitit uygarlıklarıdır. Türkiye'ye davet edilen Sümer ve Hitit uzmanlarının katkılarıyla DTCF'de Hititoloji ve dünyadaki tek örneği olan Sümeroloji kürsüsü kurulmuştur. Etibank, Sümerbank gibi kuruluş isimleri Mustafa Kemal tarafından verilmiş ve halk tarafından da bilinmesi sağlanmıştır. Bk. Ulaş Töre Sivrioğlu, Tek Parti Döneminde Orta Asya ve Sümer-Hitit Araştırmaları Celal Bayar Üniversitesi Sosyal Bilimler Enstitüsü, Tarih Anabilim Dalı, Yayımlanmamış Doktora Tezi, 2010). Anadolu halkları ve geçmiş kültürlerle Türk aile yapısının Sümer ile olan bağlantısının kurulmaya çalışılmasında, Gılgamış Destanı önemli bir argüman olarak kullanılmıştır. Böylece Sümer aile yapısı doğrudan karı-koca ilişkisi üzerine kurulu ve kutsal geleneksel örüntülerle bezenmiş bir nitelik göstermektedir. Bk. Mahmut Tezcan, Türk Aile Antropolojisi (Ankara: İmge Kitabevi, 2000), 15.

18 Güneş Dil Teorisi fikri, aslen Polonyalı olan ve Osmanlı'ya sığınarak Mustafa Celaleddin adını alan Constantin Borzecki'nin Türklerin ırksal üstünlüklerine vurgu yaptığı çalışmasında, Latin dilinin ve uygarlığının Türk kökenli olduğu savını dillendirmesine dayanmaktadır. Bk. Süreyya Su, Hurafeler ve Mitler: Halk İslâmında Senkretizm (İstanbul: İletişim Yayınları., 2011), 71.

19 Nazan Maksudyan, Türklü̈̆̈̈ Ölçmek (İstanbul: Metis Yayınları, 2007), 55-56; Suavi Aydın, "Türkiye Antropolojisi", Antropoloji Sözlüğ̈̈̈, ed. Kudret Emiroğlu-Suavi Aydın, (Ankara: Bilim ve Sanat Yayınları, 2003), 821.

20 Zafer Toprak, Darwin'den Dersim'e Cumhuriyet ve Antropoloji (İstanbul: Doğan Kitap, 2015), 70-71. 
kimlik tanımlarında fayda sağlayacağı düşünülmüştür. Kısmen başarılı olan bu uygulamalar çoğunlukla zorlama bilimsel öğretiler üzerinden yürütülmeye çalışılınca zamanla etkinliğini yitirmiş ve antropoloji Türkiye'de ırk bilimi olarak tanımlanmaktan kurtulamamıştır.

Mustafa Kemal'in hayatını kaybetmesi ve çok partili hayata geçilmesi sonrasında başta Güneş Dil Teorisi gibi bazı devlet politikalarından vazgeçilmiştir. Fakat dönemin bilim anlayışı sonraki bilimsel çalışmaları da etkilemiştir. Örneğin İbrahim Kafesoğlu 1970 tarihli Türk Milliyetçiliğinin Meseleleri adlı eserinde, tarih biliminin sayısız halklara ait bilgiler verdiğini, şüphesiz Türklere ait müstesna bilgiler aktardığını yazmaktadır. Yine Türkler hakkında kötü ifadeler kullanılmasına rağmen, Türk milletinin insanlık tarihi içinde şerefli bir yerinin olduğundan şüphe duyulmadığı dile getirilmektedir. Kafesoğlu'na göre Türkler dünyanın en eski ve en büyük milletlerinden biridir ve son yıllarda Orta Asya'da yapılan arkeolojik kazılar da tarihimizi milattan önceye kadar götürmektedir. Yaklaşık beş bin yıl kesintisiz bir medeniyet inşası içinde olmak her ulusa nasip olmamıştır. Bu da devletin gücünün bir göstergesidir ve geçmişin bu dönemlerinde Avrupa'daki milletler tarih sahnesinde değillerdir. Hatta Çin, Hint, eski Yunanlar, Romalılar, İranlılar ve daha başkaları da tarih sahnesine çıktıklarında Türklerle temas kurmuşlar ve Türklerden medeniyet unsurlarını almışlardır. ${ }^{21}$ Kafesoğlu dönemin uluslaşma çabalarının sonucu olarak belli bir düşünce içinde ulus devlet tarifi yapmaktadır. Aynı şekilde Cumhuriyet döneminin ilk dinler tarihçisi Fransız asıllı Georges Dumézil'in öğrencisi olan Hilmi Ömer Budda'nın Dinler Tarihi adlı kitabı, ilk modern dinler tarihi ${ }^{22}$ çalışması sayılabilecek nitelikte olup dönemin hâkim anlayışı olan ulus devlet ve millet düşüncesinin inşa sürecine uygun şekilde hazırlanmıştır. Budda, çalışmasında Hint, Çin ve Japon dinlerine Türk Tarih Tezi anlayışından hareketle, bu dinler ile Türkler arasında bir bağlantı kurma çabasına girmiştir. ${ }^{23}$

Hilmi Ömer Budda dinler tarihi kitabının ön sözünde, temel amacının Türk medeniyet ve kültürünün dünyaya saçtığı nurları göstermek olduğunu ifade etmiştir. ${ }^{24}$ Çalışmasına Hint medeniyetini arkeolojik veriler ışı̆̆ında değerlendirmeye başlayan Budda, Aryanlar'dan önce bölgeye gelmiş bir medeniyetin varlığına rastlandığına ve bu medeniyetin Türklerin ataları olan Sind ve Sümer medeniyetleriyle oldukça benzerlik gösterdiğine dikkat çekmiştir. Böylece Türkler Hint medeniyetine kaynaklık etmekle kalmamış, aynı zamanda Hint medeniyetine

\footnotetext{
21 İbrahim Kafesoğlu, Türk Milliyetçiliğinin Meseleleri (İstanbul: Milli Eğitim Basımevi, 1970), 2.

22 Hilmi Ömer Budda, Dinler Tarihi (İstanbul: Vakit, 1935).

23 Ali İsra Güngör, "The Turkish Contribution to the History of Religions", Numen 54/1 (2007), 73.

24 Budda, Dinler Tarihi, 4.
} 
evirilen bu medeniyetlerin İran medeniyeti üzerinde de derin etkisi olduğu vurgulanmıştır. Kitabın tüm anlatımlarında mutlaka bir Türk etkisinden söz eden Hilmi Ömer Budda, Budizmin kurucusu Budda'yı da öz Türk olarak tanımlamıştır. ${ }^{25}$

Cumhuriyet dönemi aydın ve yöneticilerine göre insanlık tarihinde neler olup bittiği önemlidir. Özellikle hayatı incelemek, insanlığın geçirdiği devrelerdeki yapısını da anlamaya yarayacaktır. O güne kadar bulunan belgelere göre din olgusuna dair en eski izler neolitik döneme kadar gitmektedir. Bu dini olgulara dair işaretler Cilalı Taş Devri'nde ilk dini olguların güneşten alınan ilhamla doğduğu sonucuna varılmıştır. Afet İnan'a göre hem güneşin hem de dilin ilk kaynağı güneşin kudretidir. İnan, Carl Christian Clemen'ın Dünya Dinleri: Nitelikleri, Tarihleri adlı eserini okuduktan sonra böyle bir kanıya varmıştır. Clemen'in iddiasına göre neolitik devir insanı din inanışını güneş sembolünde temsil etmiştir. 1937 yılındaki Alacahöyük kazısında 5 adet güneş kursundan biri bezenmiş halde bulunmuştur. Kurumun araştırma dergisi olan Belleten'nin kapağında bu bezemeli güneş kursu kullanılmıştır. Nitekim Mustafa Kemal'in öncülügüünde ortaya atılan Güneş-Dil Teorisi'nin kaynağı Alacahöyük kazısıdır. Dolayısıyla arkeoloji, antropoloji ve dilbilimin kesiştiği noktalar bu teorinin odak noktasını oluşturmuştur. ${ }^{26} \mathrm{Bu}$ teorinin yaygınlaştırılması için atılan önemli adımlardan biri Mu Kıtası ile ilgili anlatılar ve dinin kaynağının bu kıta olduğuna yönelik çalışmalar olmuştur. Mu dili ile Türkçe arasında doğrudan bağ olduğu düşünülmüştür. Bu kapsamda $\mathrm{Mu}$ halkının dini kültürü de dahil, Türk kültürüyle ilişkili olduğunu gösteren üç ciltlik bir çalışma yapılmış ve Mustafa Kemal'e sunulmuştur. ${ }^{27}$

Özellikle Mustafa Kemal'in geçmişe olan merakı ve yeni ulusun kendi kültüründen beslenmesinin gerekliliğini vurgulaması günümüzde hâlâ ilgiyle takip edilen çalışmaların ortaya çıkmasını sağlamıştır. Bu çalışmalardan biri de Yusuf Ziya Yörükân tarafından yapılmıştır. Çalışma Türklerin Müslüman olmadan önceki inançlarının tespitine yöneliktir.28 Yörükân, dinin gelişimine dair ortaya atılan görüşlerden hareketle her toplumun farklı dinlere

\footnotetext{
25 Budda, Dinler Tarihi, 222.

26 İnan, Atatürk Hakkında Hatıralar ve Belgeler, 321-328; Toprak, Cumhuriyet ve Antropoloji, 450.

27 Kemal Şenoğlu, Mayatepek Raporları: Türk Tarih Tezi ve Mu Kıtası (İstanbul: Kaynak Yayınları, 2006), 25-30.

28 Çalışmayı günümüze notlar ekleyerek hazırlayan Turhan Yörükân, Mustafa Kemal'in isteği üzerine ilgili çalışmanın kaleme alındığını ve 1932 yılında tamamlanarak kendisine takdim edildiğini ifade etmektedir. Yusuf Ziya Yörükân, Müslümanlıktan Evvel Türk Dinleri: Şamanizm (İstanbul: Ötüken Neşriyat, 2006), 7. Söz konusu eser iki cilt olarak "Müslümanlıktan Evvel Türk Dinleri” ve “Müslümanlıktan Sonra Türk Mezhepleri” olarak hazırlanmıştır. Her iki kitap da 1950 yılında Yusuf Ziya Yörükân tarafından ve daha sonra Turhan Yörükân tarafından Atatürk'ün Çankaya Köşkü'ndeki kitaplığında aranmasına rağmen bulunamamıştır. Bugün için elimizde bulunan nüsha ise orijinal el yazmaları dikkate alınarak Latin harfleriyle daktilo edilmiş nüshası örnek alınarak hazırlanmıştır.
} 
ya da dini geleneklere sahip olabileceğini ifade etmektedir. Buna göre her toplumun kendine göre bir dini başlangıç aşaması vardır. Kimilerine göre bu animizm veya natürizm, kimilerine göre de fetişizmdir. Bu aşama Türklerde Şamanizm olup zamanla değişim ve dönüşüme uğramıştır. $\mathrm{O}$, dinin, kişinin ruhunda korku, sevgi veya rüya yoluyla ortaya çıktığı şeklindeki Avrupalıların görüşünü benimsemektedir. Buna göre en geleneksel din tasavvuru animizmdir. Kişinin toplumsal bir varlık olmasından dolayı din bu toplumsallığın zaruri sonucu olarak ortaya çıkmaktadır. Yörükân'a göre kişinin yüce kuvvete duyduğu korku, inanma ihtiyacını ortaya çıkarmaktadır. Yörükân animizmin yanında totemizmi de en basit din olarak kabul etmektedir. ${ }^{29}$

Dönemin tartışma ortamında dinle ilgili çalışmalar Türk kültürü içinde devam etmiş, birçok alanla (örf, gelenek, aile yapısı, dil vb.) birlikte araştırma konusu yapılmıştır. ${ }^{30}$ Anlaşıldığı üzere Cumhuriyetin kuruluş felsefesinde dine dair ihtiyatlı bir yaklaşım söz konusudur. Bu bakımdan din Cumhuriyet döneminin gündelik hayatının bir tartışma nesnesi haline gelmiştir. Ancak dini alanda olumlu sayılacak adımlar da atılmıştır. Bu dönemde Diyanet İşleri Reisliği'nin (bugünkü adıyla Diyanet İşleri Başkanlığı) kurulmuş olması, Kur'an'ın meal ve tefsirinin yapılması, Hadis alanında kitapların çevrilmesi dini alanda yapılan yeniliklerden bazılarıdır. ${ }^{31}$

Cumhuriyet dönemi aydın ve yöneticileri dini alana yönelik bazı eleştirel tutumlara sahip olsalar da dini tümden gereksiz bir olgu olarak görmemişlerdir. Bu bakımdan sürece göre hareket eden dönemin aydınları, geleneksel yaşam tarzına hâkim olan ve gündelik yaşam tarzında din ve dini gelenekleri önemseyen Anadolu insanına karşı daha 1lımlı bir tutum içinde olmuşlardır. Bu bakımdan Cumhuriyet'in kuruluş yıllarında Türkiye'de eski kültürel unsurların incelenmesine olan ilgi aynı zamanda dini alandaki merakı da beraberinde getirmiş ve kimi zaman belli politik kaygılarla bu çalışmalar sürdürülmüştür. Dolayısıyla tümden reddetmek yerine dinin toplumsal bir gereklilik olduğu ve çoğunlukla kültürel dokunun önemli bir parçası olarak kabulü söz konusudur.

\footnotetext{
29 Yörükân, Müslümanlıktan Evvel Türk Dinleri: Şamanizm, 13.

30 Bu dönemde hem dini alanda yapılan çalışmalara yönelik bazı olumsuz tavırlar söz konusuyken, aynı zaman da dini yayınların hazırlanmasında meydana gelen özensizliklere karşı da itirazlar söz konusudur. Bk. Halis Ayhan, Türkiye'de Din Eğitimi (İstanbul: DEM Yayınları, 2004), 111-116.

31 Osman Ergin, Türk Maarif Tarihi 1-2 (İstanbul: Eser Matbaası, 1977), 282.
} 


\section{Cumhuriyet Dönemi Dinler Tarihi Çalışmalarında Antropolojinin Etkisi}

Türkiye'deki Dinler Tarihi kitapları kapsamında değerlendirilebilecek ilk örnekler İslam Tarihi kitapları olarak yazılan, içeriğinde bazı eski inançlar ve İslam dışı uygulamalara değinilen çalışmalardır. Bunlar mitolojik özellikler taşıdıklarından dinler tarihi içerisinde değerlendirilebilir. Şemseddin Sami tarafından yazılan Esatir (1878) bu alandaki ilk örneklerin başında gelir. ${ }^{32}$ Batı'da mitoloji üzerine çok sayıda çalışmanın olması Sami'nin dikkatini çekmiş ve bu konuda hem merakını gidermek hem de başkalarını bilgilendirmek için bir kitap hazırlamıştır. Eser, dinler tarihi ve mitoloji açısından metodolojik olarak yetersiz ve eleştirilen yönleri bulunmakla birlikte, dönemin kayda değer ilk çalışması olması hasebiyle önem kazanmaktadır. Sami'nin inanç olgusuna yaklaşımı kişisel düşüncesini yansıtmakta ve bilimsel anlayıştan uzak gözükmektedir. O, doğru yolu bulup Tanrı'yı bulanları aydınlıkta, geri kalan çoğunluğu ise karanlıkta kalanlar olarak nitelendirmektedir. Ona göre, insanlar geçen zaman diliminde ortaya çıkartılan garip inançlar ve ritüellerle kocaman bir inanç dünyası oluşturmuşlardır. ${ }^{33}$ Sami, toplumlar arası inanç farklılıklarını antropolojik bir bakış açısıyla evrimsel sürece indirgeyerek açıklamıştır. ${ }^{34}$

Sami'den sonra antropolojik nitelikte önemli dinler tarihi çalışmaları yapanların başından Mehmet Şemseddin Günaltay (1883-1961) gelmektedir. Günaltay, Osmanlı ile Cumhuriyet arasında dinler tarihi biliminin taşıyıcılığını yapan kişi olarak tanımlanabilir. Osmanlı'nın son dönemlerinde Tarih-i Edyan (Dinler Tarihi) derslerini okutmuş ve daha önce okutulan ders kitaplarına daha derli toplu bir biçim getirmiş ve yararlanılan kaynakların belirtildiği bir kitap da yazmıştır. Tarihçi bir kimliğe sahip olan Günaltay, İslamcı bir çizgide siyaset yapmış, Türkçülük ve İslam'ı aynı anda benimsemiştir. ${ }^{35}$ Özellikle pozitivist anlayışın etkisinde kalarak dinler tarihini daha çok din felsefesi bağlamında düşünmüş, Hristiyanlık ve İslamiyet gibi yaygın dini geleneklerin aksine kabile dinleri, Uzakdoğu ve Çin dinlerine ilgi duymuştur. Dinin kaynağını tespite yönelik arayışları pozitivist anlayışın tesirinde olduğunu göstermektedir. ${ }^{36} \mathrm{Bu}$ tespitleri din tanımında bariz bir şekilde görülmektedir. Günaltay,

32 Galip Atasağun, "Türkiye'de Dinler Tarihi Çalışmaları", Necmettin Erbakan Üniversitesi İlahiyat Fakültesi Dergisi 20/20 (2005), 206. Bu eser Cengiz Batuk tarafından günümüz Türkçesi göz önünde bulundurularak yeniden gözden geçirilmiş ve ayrıntılı bir giriş bölümü eklenerek basımı sağlanmıştır. Bk. Şemseddin Sami, Esatir: Dünya Mitolojisinden Örnekler, çev. Cengiz Batuk (İstanbul: İnsan Yayınları, 2007).

33 Sami, Esatir, 21-22.

34 Sami, Esatir.

35 Abdurrahman Küçük, "Tanzimattan Günümüze Türkiye'de Dinler Tarihi", Türkiye'de Dinler Tarihi (Dünü, Bugünü ve Geleceği), ed. Ali İsra Güngör vd. (Ankara: Türkiye Dinler Tarihi Derneği Yayınları, 2010), 342.

36 Mahmut Aydın, Anahatlarıyla Dinler Tarihi (Samsun: Ensar Neşriyat, 2013), 75. 
yeryüzündeki insan topluluklarını gelişmişlik durumuna göre basitten karmaşığa doğru evrimsel sınıflandırmaya tabi tutmuştur. ${ }^{37}$

Günaltay, Dinler Tarihi isimli çalışmasında batıdaki din çalışmalarının geçmişine değinmekte ve çalışmasında özellikle dinin kutsallık boyutunun diğer milletlerde nasıl ortaya çıktığını batılı bilim insanları üzerinden ele almaktadır. Dinler tarihi çalışma yöntemlerini de değerlendiren Günaltay dinleri sınıflamanın birtakım problemleri de beraberinde getirdiğini vurgulamaktadır. Günaltay'ın bu çalışması konu ve kapsam bakımından Batı'daki tartışmaları ele alması açısından dönemin bilim anlayışına büyük bir katkı olarak değerlendirilebilir. ${ }^{38}$

Günaltay, din ve dini olgulara ilişkin yaklaşımında çoğunlukla antropolojik anlatım biçimlerinden ve bakış açısından faydalanmıştır. $\mathrm{O}$, dinin anlaşılabilir olması için birtakım olgulardan hareketle, sadece metafizik açıdan dinin anlaşılamayacağına, toplumsal düzeni sağlayıcı özelliği olan dinin kurumsal bir olgu olduğuna dikkat çekmiştir. Bu bakımdan Günaltay dini önemsemekte ve düzen açısından gerekli görmektedir. Günaltay dini olgulara ilişkin karşılaştırmalarda genelde hâkim evrimsel görüş olan basitten karmaşığa doğru olan görüşü savunmuştur. Çalışmalarında Arapların antropolojik açıdan analizini yapmış ve yoğun betimleme içeren analizlerini çok sayıda etnografik veri ile desteklemiştir. Ele aldığı bölgenin coğrafik yapısı hakkında ayrıntılı bilgi veren Günaltay, oradaki hâkim etnik unsurların ya da aynı etnik gruba sahip farklı kabilelerin birbirleriyle paylaştıkları dil ve kültürel etkileşimleri ayrıntılı bir şekilde ele alarak kültürel boyutun toplumun dini yapısındaki etkisine dikkat çekmiştir. ${ }^{39}$

Günaltay, yaşadığı dönemde dinler tarihi açısından derli toplu bilgiler veren kişilerin başında gelmektedir. Bu bakımdan dinler tarihi bilim anlayışımızın gelişmesinde önemli bir şahsiyettir. Dönemin toplumsal anlayışını pozitivist paradigmayla çözümleme yoluna gitmesine karşın, olayların mantıki ilişkilerini kültürel olguları göz ardı etmeden anlatabilme becerisiyle başlangıç olması açısından Türk dinler tarihçiliğine önemli katkılar yapmıştır.

Günaltay'dan sonra Fransız vatandaşı olan Georges Dumézil (1898-1986) dinler tarihi hocası olarak göreve başlamıştır. Dumézil, 1924-1927 yılları arasında, başlangıçta İstanbul'da

\footnotetext{
37 M. Şemseddin Günaltay, Dinler Tarihi: Yeryüzündeki İlkel Dinler (İstanbul: Kesit Yayınları, 2006), 15.

38 Günaltay, Dinler Tarihi, 58. M. Şemseddin Günaltay'ın, çoğunlukla geleneksel dinlere ayırdı̆̆ı kitabına dair kapsamlı bir değerlendirme için bk. Ahmet Gökbel, "M. Şemseddin (Günaltay) ve Dinler Tarihine Yaptığ1 Katkılar", Fırat Üniversitesi İlahiyat Fakültesi Dergisi 5 (2000).

39 M. Şemseddin Günaltay, İslam Öncesi Araplar ve Dinleri (Ankara: Ankara Okulu Yayınları, 2013).
} 
daha sonra kısa bir süre Ankara'da ders vermiştir. ${ }^{40}$ Dumézil Türkiye'de kaldığı altı yılın iki yılını İlahiyat fakültesinde dinler tarihi dersi vererek tamamlamıştır. ${ }^{41}$

Dumézil'in Türkiye'deki dinler tarihi uğraşı daha sonraki akademik hayatında büyük bir ilerleme yapmasını sağlamıştır. Türkiye'de bulunan Çerkez ve alt grupları hakkında ayrıntılı çalışmalar yapmıştır. Dumézil alan çalışması olarak sürdürdüğü bu süreci, sadece mitolojik öğelerin farklı coğrafyalarda nasıl yer aldığını karşılaştırmakla yetinmemiş, 1927 yılından itibaren belli aralıklarla çeşitli Çerkez yerleşim yerlerinde alan araştırması yaparak çalışmalarını sürdürmüş ve yayımlamıştır. Dumézil Türkiye'den ayrıldıktan sonra da düzenli olarak ziyaretlerde bulunmuş ve 1952'den 1972 yılına dek her yaz araştırma yaptığı Çerkez köylerinde dil, kültür, mitolojik açıdan bilgiler elde etmiş ve Çerkez, Gürcü, Laz dilleri ve lehçeleri; Avar, Çeçen ve İnguş dilleri ve lehçelerini, Abhaz ve Ubih dillerini öğrenerek Kafkas halklara olan ilgisini derinleştirmiştir. ${ }^{42}$

Dumézil, Kafkas Halkları Mitolojisi adlı eserinde, Kafkas bölgesinin tarihi hakkında ayrıntılı bir giriş yaptıktan sonra bölgenin etnografyasına ilişkin bilgiler sunmaktadır. Halklara ait gündelik yaşam, dini özellikler, çevre bölgelerle ve etnik gruplarla olan ilişkiler, kültürel benzerlik ve farklılıklar, siyasal durumlar gibi ayrıntılara yer vererek çalışmasına kültürel açıdan derinlik katmıştır. Dumézil aynı zamanda kaydettiği mitolojik bilgilerle sözlük niteliğinde olan çalışmasını tamamlamıştır. ${ }^{43}$

Dumézil, Türkiye'de bulunduğu süre boyunca antropoloji mensupları ile iletişim halinde olmuş ve Antropoloji Mecmuasında çalışmalarını yayımlamıştır. İran, Hint, Türk, Moğol, Sümer, Asur, Yunan ve diğer yakın coğrafyalarda yaşayan halkların yanı sıra Avrupa halkları hakkında etnografik ve bu uygarlıkların dini yapılarına dair ayrıntılara yer vermiştir. ${ }^{44}$ İskandinav ile Hint mitolojik unsurlarının benzerliklerine ve Anadolu'daki kimi efsanevi kahramanların bunlarla olan bağlarına dikkat çekmiştir. ${ }^{45}$

\footnotetext{
40 Adnan Ekşigil, "Georges Dumézil", Tarih ve Toplum 42 (1987), 49.

41 Dumézil tarafından verilen derslerin Osmanlıca olarak basılmış hali Fuat Aydın ve Feyza Betül Aydın tarafından yayıma hazırlanmış ve Fuat Aydın tarafından kitaba Dumézil hakkında bir giriş bölümü eklenerek Türkçeye kazandırılmıştır. Ayrıntılar için bk. Fuat Aydın-Feyza Betül Aydın, Georges Dumézil'den Dinler Tarihi Dersleri (Ankara: Eski Yeni Yayınları, 2012), 19; Gündüz Vassaf (ed.), Belkıs Halim Vassaf'ın Defterinden Dumézil'in Sosyoloji Ders Notları (İstanbul: Boğaziçi Üiversitesi Yayınevi, 2009), 13-14. Dumézil'in dinler tarihinden sonra verdiği sosyoloji dersleri Belkıs Halim Vassaf tarafından notlar halinde tutulmuş ve bu notlar Ali Akay ve A. Sumru Özsoy'un Dumézil hakkındaki birer çalışması da eklenerek Gündüz Vassaf tarafından yayımlanmıştır. Bk. Vassaf, Dumézil'in Sosyoloji Ders Notlart.

42 Aydın-Aydın, Dinler Tarihi Dersleri, 23.

43 Georges Dumézil, Kafkas Halkları Mitolojisi, çev. Musa Yaşar Sağlam (Ankara: Ayraç Yayınları, 2000).

44 Hakan Kurt, Türk Antropoloji Macmuası Transkripsiyonu 1925-1928 (Ankara: Gece Kitaplı̆̆1, 2017), 75-84.

45 Vassaf, Dumézil'in Sosyoloji Ders Notları, 8.
} 
Dumézil'in dinler tarihçiliği büyük oranda antropolojik bakış açısından beslenmiştir. Max Müller ve okuluna mensup olanların sebep olduğu, çoğunlukla abartılı, zaman zaman da uydurma olduğu gerekçesiyle eleştirilen 19. yüzyıl karşılaştırmalı mitoloji çalışmalarının yeniden yorumlanmasına kendisini adayan Dumézil, Hint-Avrupa medeniyetine odaklanmış olsa da Hindistan, Kuzey Afrika, Avrupa, İskandinav kültürlerine ilgi duymuş ve kaynaklarına atıfta bulunmuştur. Dumézil'in temel çalışma prensibi, filoloji, sosyoloji, antropoloji bilimlerden faydalanarak, farklı medeniyetler olarak Hint ve Avrupa'nın benzer ve farklı taraflarına odaklanmıştır. O'nun amacı alışageldiği gibi bu medeniyetler arasındaki ilişkiyi ilkin evrim düşüncesiyle daha sonra sistem, en son olarak da bunların birbirinden ayrılmadan önceki oluşturdukları ortak yapı düşüncesinden hareketle aydınlatmaya çalışmaktır. Dumézil, tanrı tipleri ile toplumsal yapı ve ideolojiler arasında yakın bir ilişki kurmuştur. Ona göre bu bir tür keşiftir ve üçlü yapı hiyerarşik bir düzene sahiptir. ${ }^{46}$ Bunlar mit ve destanlarda görünür hale gelmişlerdir. Buna göre hâkimiyeti temsil eden tanrılar, yeryüzünde yargısal görevle sorumlu olan din adamları sınıfıyla görünür hale gelirken, düzeni temsil eden savaşçı tanrılar, gücü temsil eden savaşçılarla temsil edilir ve bereket tanrıları da yeryüzünde bitkilerin ve hayvanların sürekliliği işiyle uğraşan çobanlar ve çiftçiler olarak görünür hale gelirler. Bu şekilde medeniyetlere ait mitolojik çözümlemeler yaparak anlamaya çalışan Dumézil, farklı olmalarına rağmen ortak kültürel olgular üzerinden kurduğu bu sembolik anlatımla çoğu medeniyet arasında sıkı ilişkiler ağını ortaya çıkardığını düşünmektedir. ${ }^{47}$ Ona göre Eski İran ve Hint toplumlarının üçlü kasta bölünme biçimiyle eski Roma dininin üç tanrıya göre şekillenmesi arasında doğrudan bir benzerlik hatta paralellik söz konusudur. Dumézil bu üçlü yapıyı din adamları, savaşçı ve üreticilerin işlevlerine göre belirlendiğini savunmaktadır. O'nun temel amacı sistematize ettiği üçlï işlev ${ }^{48}$ fikrinden hareketle Hint-Avrupa menşeli toplumların düşünsel yapı ve bu yapı arasında ayırt edici özelliklerini tarihsel seyir içinde geçirmiş olduğu değişim ve dönüşümü anlamak ve anlaşılmasını sağlamaktır. ${ }^{49}$

46 Mustafa Ünal, Din Fenomenolojisi: Tarihçe, Yöntem ve Uygulama (Kayseri: Geçit Yayınları, 1999), 58.

47 Aydın-Aydın, Dinler Tarihi Dersleri.

48 Dumézil ile yapılan bir mülakatta, kendisine üç işlevin neden evrensel değil de Hint-Avrupalı olduğu üzerine sorulan soruya şu cevabı vermiştir: “Üç işlev aslında önce doğada vardır: beyin, kaslar ve ağız bireylerin ve toplumların hayatlarını yönetmektedirler. Ve kendini yönetmek, kendini savunmak ve kendini yeniden üretmek herhangi bir toplumda karşımıza çıkmaktadır." Dumézil bu uyumun Hint-Avrupa dışındaki toplumlarda sağlanamadığını, toplumsal rollerde bazı değişimlerin ve geçişlerin olduğunu ifade etmektedir. Bk. Georges Dumézil, "Georges Dumézil'in Gizli Şölenleri", Tarih ve Toplum 42 (1987).

49 Ekşigil, "Georges Dumézil", 50,51. 
Dumézil'in, çalışmalarından etkilendiği Max Müller tümüyle birbirinden ayrı gibi gözüken diller arasında yakın ilişkiler keşfetmiş ve Avrupa dilleri ile Sanskritçe arasında köken bağları kurmuştur. O, Hint-Avrupa filologlarının Avrupa dillerinin köken bakımından Hindistan'dan geldiklerine inanmaktaydı. Dumézil, karşılaştırmalı mitoloji çalışmalarında filoloji bilimini kullanarak Müller'den sonra adeta kaderine terk edilen karşılaştırmalı mitoloji çalışmalarını ayağa kaldırmıştır. ${ }^{50}$ Özellikle kaybolmaya yüz tutmuş sosyolojik, antropolojik ve felsefi bakış açısını karşılaştırmalı dinler tarihine uygulamada büyük başarı sağlamıştır. ${ }^{51}$ Bu bakımdan Mircea Eliade, Dumézil'i yerel kültürlere ilişkin ortaya çıkan zengin morfolojik malzemenin görünür hale gelmesindeki başarısıyla Frazer ile birlikte de anmaktadır. ${ }^{52}$

Dumézil'in bilim anlayışında İskitlerden İran'a, İskandinavya'dan Eski Yunan'a, Roma'dan Cermenlere ve hatta Hindistan'a kadar uzanan geniş bir coğrafi alanın izlerini görmek mümkündür. Bu coğrafya içinde İskandinav ile Hint mitolojik unsurlarının benzerliklerine ve Anadolu'daki kimi efsanevi kahramanların bunlarla olan bağlarına dikkat çekmiştir. ${ }^{53}$

Dumézil'in Türkiye'de bulunduğu süre zarfında çalışmalarının yanı sıra Hilmi Ömer Budda'ya (1894-1952) doktora yaptırmıştır. Budda'nın 1935 yılında hazırladığı dinler tarihi kitabı çoğunlukla dönemin Türk ulus devlet idealine uygun bilim yapmak üzerine kurgulanmıştır. Bu bakımdan bilimsel açıdan tartışılacak bir çalışma olmasına karşın, dönemin koşulları itibariyle övgüyü hak eden bir çaba olarak ele almakta fayda vardır. Dumézil'in bilim anlayışının kısmen Budda tarafından sürdürüldüğünü söylemek yerinde olacaktır. Budda karşılaştırmalı mitoloji ve dilbilim yöntemlerini odak noktası yaparak dinler tarihi ders kitabı yazmıştır.

Budda'nın dinler tarihi kitabı dışında göze çarpan diğer çalışması ise Sami dinlerinde kurban geleneği ile alakalı olup 1928 yılında İlahiyat Fakültesi Dergisinde yayımlanmıştır.54

\footnotetext{
50 Dumézil Mit ve Destan I adlı eserinde Max Müller'i belli tezleri mitlerin tamamına ve tüm mitolojilere yaymasını eleştirmektedir. Ona göre "Bugün, bir mitolojik külliyat karşısında daha alçakgönüllü davranmak, onu kullanmaktan ziyade ona hizmet etmek, sorgulamak, özellikle de zenginliğine, çeşitliliğine, hatta çelişkilerine sayg1 duymak" gerekmektedir. Bk. Georges Dumézil, Mit ve Destan I: Hint-Avrupa Halklarının Destanlarında Üç İşlev İdeolojisi, çev. Ali Berktay (İstanbul: Yapı Kredi Yayınları, 2012), 36.

51 Ünal, Din Fenomenolojisi: Tarihçe, Yöntem ve Uygulama, 58.

52 Mircea Eliade, Dinler Tarihi: İnançlar ve İbadetlerin Morfolojisi, çev. Mustafa Ünal (Konya: Serhat Kitabevi, 2005), 470.

53 Vassaf, Dumézil'in Sosyoloji Ders Notları, 8.

54 H. Ömer Budda'nın muhtelif çalışmaları bir ara getirilerek Bekir Zakir Çoban tarafından Kurban ve Tufan Üzerine Makaleler adıyla yayımlanmıştır. Çalışmanın içeriği hakkında geniş bilgi için bk. Hilmi Ömer Budda, Kurban ve Tufan Üzerine Makaleler, çev. Bekir Zakir Çoban (İstanbul: İnsan Yayınları, 2003).
} 
Çalışmasına teorik zemin oluşturmak amacıyla kaynak gösterdiği çalışmaların sahipleri olan Tylor, Frazer, Smith başta olmak üzere dönemin bilinen antropolog ve bir kısmı aynı zamanda sosyologlardan oluşmaktadır. Budda, kurban fenomeninin kültürel arka planına ışık tutmaya çalışmakta, kutsallık atfedilen mekânların Tanrı tarafından ziyaret edildiğine olan inancın zamanla insanlar için ziyaret yeri olarak kabul edildiğini ve kutsallık kazandırılarak buradaki taş gibi nesnelerin ilahi varlıklar olarak kutsallaştırılmaya başlanmasıyla bunlara saygıda bulunmanın kurban olayını başlattığını ifade etmektedir. 55 Örneğin evlenme, çocuk sahibi olma, erkeklik yaşına girme, ilk ürünün hasadı gibi toplumun tümünü ya da belli bir kısmını ilgilendiren özel anlara kutsallık atfedilmesiyle bu uygulamalar zamanla bir ritüele dönüşmüştür. Dolayısıyla zamanla ritüele dönüşen bu uygulamalar Budda'nın Arnold van Gennep'tan aktardığı haliyle tabu ile ilişkili görülmektedir. İlk mahsulden yiyebilmek, ilk olanı serbestçe yapabilmek, ona dokunabilmek ya da kutsallık atfedilen üzerindeki tabuyu kaldırabilmek için kurban şart koşulmaktadır. ${ }^{56}$ Burada çoğu geleneksel toplumda görülen uygulamalar örnek gösterilerek zamanla bunun daha yüksek bir kültür öğesine dönüşerek İbraniler ve diğerlerinin günümüz kurban olgusuna kaynaklık ettiğine işaret edilmektedir. Budda'nın dipnotlarda verdiği örnekler oldukça zengin bir içeriğe sahiptir. Bu örnekleri faydalandığı kaynakların çoğunlukla antropoloji çalışmaları olması konuya ilgisini anlamamız açısından önemlidir.

Budda'nın, kültürleri aşağıdan yukarıya doğru birbirinden beslenen gelişim süreci olarak kabul edip pozitivist anlayışla açıklaması dönemin uluslaşma anlayışının bir yansıması olarak değerlendirilebilir. Türk kültürünün birçok medeniyete kaynaklık ettiği düşüncesiyle yapılan çalışmalara Budda'nın dinler tarihi çalışması dahil edilebilir. Kültürel ve zihinsel kodların geçmişi kurgulamadaki gücü maddi kültür unsurlarının daha iyi içselleştirilmesine katkı yaptığından, Baki Adam'a göre Budda'nın Türk Tarih Tezi odaklı ele aldığ1 konular ve bu yönde kullandığı üslup Dinler Tarihi'nin Türkiye'de olumsuz algilanmasında rol oynamıştır. ${ }^{57}$

Budda'nın dinler tarihi kitabından sonra, Ömer Rıza Doğrul 12 yılın ardından halka dönük bir çalışma yapmış ve bir dinler tarihi kitabı hazırlamıştır. ${ }^{58}$ Doğrul'un dinler tarihi

\footnotetext{
55 Budda, Kurban ve Tufan Üzerine Makaleler, 18.

56 Budda, Kurban ve Tufan Üzerine Makaleler, 91-92.

57 Baki Adam, "Annemarie Schimmel'den Prof. Dr. Abdurrahman Küçük'e Ankara İlahiyat'ın Türkiye'deki Dinler Tarihi Çalışmalarına Katkısı", Türkiye'de Dinler Tarihi'nin Kurumsallaşması Sürecinde Prof. Dr. Abdurrahman Küçük, ed. Ahmet Hikmet Eroğlu (Ankara: Berikan Yayınevi, 2016), 136.

58 Küçük, "Tanzimattan Günümüze Türkiye'de Dinler Tarihi", 348.
} 
bilimine ilişkin yaklaşımı oldukça sübjektiftir. Kitabın başlığının altında çerçeve içinde "iptidaî dinlerden başlayarak bütün dinleri tetkik eden tam bir dinler tarihidir" şeklinde oldukça iddialı bir ifade kullanılmıştır. Bu durum kendinden önceki dinler tarihi çalışmalarını pek kayda değer bulmadığı ya da eksik bulduğu düşüncesini ortaya çıkarmaktadır. Kaldı ki Doğrul, kitabın ön sözüne dinin doğuşuna ilişkin “bizim kendimize göre bir İslami telâkkimiz vardır ki ilmin onu teyit etmediği söylenemez" şeklinde bir girişle başlamaktadır. Doğrul'un dinin kaynağına ilişkin yaklaşımı çoğunlukla teosentriktir. O'na göre insan yaratılış olarak en mükemmel şekilde yeryüzüne gönderilmiş fakat zamanla sapkınlığa yönelmiştir. ${ }^{59}$

Doğrul'un dinler tarihi kitabı alışılageldiği gibi, antropolojik bir kategori olarak iptidai aşamadan tek tanrılı dinlere doğru bir anlatımla başlamaktadır. Doğrul da dinin ilk halinin "vahşi" olarak adlandırdığı geleneksel yaşam biçimine sahip, basit kabile yaşamı sürdüren toplulukların anlamlandıramadığı her türlü gizemli güce saygıda bulunmasıyla dini yaşantı içinde bulunduğunu ifade etmektedir. Doğrul'un bu anlatımları oldukça basit ve anlaşılır bir üsluptadır. Din devrinden önceki aşama olarak büyü, putperestlik, tabu, şamanlık şeklinde bir sıralama mevcuttur. İlkel dini ve düşünce dönemi olarak adlandırılan bu aşamadan sonra “Din Devri" aşamasına geçilmiş, bu da dinin bir tekâmüle uğradığı anlamına gelmektedir. ${ }^{60}$

Doğrul, eserinin giriş kısmında Kur'an dışındaki bilgilere pek itibar etmediğini açıkça ifade etmiştir. Buna rağmen kurgusal olacak bilgilerle kitabına başlaması ilginç bir durum teşkil etmektedir. Buradan anlaşılmaktadır ki Doğrul, dinler tarihine kaynaklık eden antropolog James George Frazer (1854-1941) başta olmak üzere dönemin dinler tarihçilerinin verilerini kullanmıştır. ${ }^{61}$ Doğrul'un dönemin Batı merkezli öteki ulusların geçmişine dönük ilginin sonucu olarak ortaya çıkan dini geleneğe yönelik ilgisi de hâkim pozitivist bilim anlayışının etkisinde olduğunu göstermektedir. Doğrul, antropolojik verileri kullanmakta herhangi bir sakınca görmezken, bu bilgilere oldukça ihtiyatlı yaklaştığını açıkça beyan etmektedir.

Annemarie Schimmel'e (1922-2003) kadarki süreçte, özellikle Cumhuriyet dönemi bilim anlayışı ulus devlet düşüncesinin destekleyicisi konumunda ve okutulan derslerin ve içeriklerinin laikleşme çabalarının bir sonucu olarak yoğunlukla sosyolojik ve felsefi bakış açısının hâkim olduğu bir anlayışla verilmiştir. Dönemin dersleri ve yazılan ders materyalleri

\footnotetext{
59 Ömer Rıza Doğrul, Yeryüzündeki Dinler Tarihi (İstanbul: Ink1lâp Kitabevi, 1947), 5.

60 Doğrul, Yeryüzündeki Dinler Tarihi, 26.

61 Doğrul, Yeryüzündeki Dinler Tarihi, 39.
} 
doğal olarak talep görmemiştir. “Schimmel'in 1954 y1lında dinler tarihi kürsüsüne atanmasıyla antropolojik, sosyolojik, psikolojik, felsefi hiçbir faktöre indirgenemeyecek" derecede kutsal kavramını merkeze alan bir anlayış ülkemizin bilim anlayışı olarak başlamıştır. ${ }^{62} \mathrm{Bu}$ anlayış, Türklerin dini kültürünün araştırılmasında kutsalın tespiti için yapılan etnografik din antropolojisi çalışmalarına da önemli ölçüde kaynaklık etmiştir.

Schimmel'in Türkiye'ye olan ilgilisi doktora çalışması olarak İslam tasavvufunu konu edinmesiyle başlamıştır. Rudolf Otto'nun geniş bir perspektiften ele aldığı din ve buna bağlı olarak kutsal ifadesi Schimmel'in dinler tarihi anlayışına büyük etki etmiştir. ${ }^{63} \mathrm{O}$, oryantalist bir tavır takınmak yerine İslam'ı anlama çabası içinde bulunmuştur. Özellikle Türk kültürüne ve buna bağlı olarak da Doğu toplumlarına olan ilgisi Türk dini tarihi ve Anadolu halk inançlarının daha sonra akademik çalışmalara konu edinmesinde oldukça belirleyici olmuştur. Zira bu alanda yetişen Hikmet Tanyu'nun (1918-1992) Anadolu inançlarına olan ilgisi Schimmel'in kutsalın anlaşılmasına verdiği önemin devamı niteliğindedir. Bu bakımdan Tanyu, Schimmel'in tasavvuf ağırlıklı kutsal anlayışını dinler tarihi perspektifinden yorumlamıştır. Özellikle Tanyu'ya kadarki süreçte İslami öğelerin çokça vurgulandığı, manevi değerlerin ön planda tutulduğu bir bilim anlayışı pek tercih edilmemiş, çoğunlukla laiklik vurgusunun başat olduğu, seküler bir toplum oluşturma çabalarının hâkim olduğu bir bilim anlayışı ön planda tutulmuştur. Dolayısıyla Tanyu ile hem İslami hem de milli olan bir dinler tarihi anlayışı ortaya çıkmıştır.

\section{Hikmet Tanyu'nun Çalışmalarında Din Antropolojisi Yaklaşımı}

Türkiye'de Türk Dinî Tarihi araştırmaları tartışmasız Hikmet Tanyu ile başlamıştır. ${ }^{64}$ Annemarie Schimmel'in kutsal anlayışının Tanyu tarafından devam ettirilmesi, İslam dininin

62 Adam, "Annemarie Schimmel'den Prof. Dr. Abdurrahman Küçük'e Ankara İlahiyat'ın Türkiye'deki Dinler Tarihi Çalışmalarına Katkısı", 137.

63 Fethullah Kalın, Rudolf Otto'da Din, Kutsallı ve Mistik Tecrübe (İstanbul: Ötüken Neşriyat, 2014), 65-66.

649 Ocak 1918'de Ankara'da doğan Hikmet Tanyu, Ankara Üniversitesi Dil ve Tarih-Coğrafya Fakültesi Felsefe Bölümünden 1948 yılında mezun olmuştur. 1955 yılında Ankara Üniversitesi İlâhiyat Fakültesi Dinler Tarihi Kürsüsüne Annemarie Schimmel'in asistanı olarak atanmış, 1959'da Ankara ve Çevresinde Adak ve Adak Yerleri başlıklı teziyle Türkiye'nin ilk dinler tarihi doktoru olmuştur. Konunun ana çerçevesinin anlaşılmasında ve Tanyu'nun din antropolojisi açısından konu ve yöntem yakınlığına dikkat çekmek için yapmış olduğu belli başlı çalışmaları şu şekilde sıralamak mümkündür: Ankara ve Çevresinde Adak ve Adak Yerleri; Türklerde Taşla İlgili İnançlar; Türklerin Dini Tarihçesi; İslamlıktan Önce Türklerde Tek Tanrı Inancı; Dinler Tarihi Araştırmalarl; Türklerde Ağaçla ilgili inançlar; Başka Ülkelerde Adak ve Adak Yerleri; Dini Folklor veya Dini-Manevi Halk İnançlarının Çeşit ve Mahiyeti Üzerine Bir Araştırma; Türklerde Ateşle İlgili İnançlar; Türklerde Muhtelif Dinlere Dair Bir İnceleme. Bk. Münir Yıldırım, "Türk Dini Tarihi Araştırmalarında Fenomenolojik Metod: Hikmet Tanyu Örneği", Türkiye'de Dinler Tarihi (Dünü, Bugünü ve Geleceği), ed. Ali İsra Güngör vd. (Ankara: Türkiye Dinler Tarihi Derneği Yayınları, 2010), 63-64. Hikmet Tanyu hakkında çok sayıda çalışma olmakla birlikte, Tanyu'nun düşünce dünyasına dair en ayrıntılı çalışmalar için bk. Günay Tümer, "Hocamız Hikmet Tanyu", Erciyes Üniversitesi Sosyal 
pozitivist bakış açısıyla yorumlanmasının da önüne geçmiştir. Schimmel'in kutsala olan bakış açısı pozitivist din anlayışının aksine, insanın birtakım doğa olayları ya da yaşadığı farklı deneyimlerin sebebiyet verdiği bir anlamlandırma ve adlandırma durumu değil, var olan ruhun kutsalın anlaşılmasında yegâne rol oynadığını ifade etmekte ve böylece farklı bir kutsal tarif etme zorunluluğu da ortadan kalkmaktadır. Dolayısıyla Müslüman bir şahsiyet olarak, ulus devlet anlayışının hâkim olduğu bir geleneğin içinde yetişen, bu bakımdan din ve milli geleneğin değerinin farkında olan Hikmet Tanyu, Schimmel'den edindiği bu bilim anlayışını İslam ve Türk kültürünün anlaşılmasında akademik bir uğraş olarak yeni bir çalışma alanı oluşturmuştur. Böylece Tanyu Ekolü olarak adlandırılan bir disiplinin öncüsü olmuştur.

Hikmet Tanyu'ya kadar Türklerin dini geçmişine dair çalışmalar oldukça sınırlıdır. İslam öncesi Türkler hakkında akademik nitelikli çalışmalara bakıldığında Ziya Gökalp ve M. Fuat Köprülü isimleri ön plana çıkmaktadır. ${ }^{65}$ Türklerin inançları konusunda da bir kafa karışıklığı mevcuttur. Bu bakımdan Tanyu'nun bu tür geçmişe dönük derlenen bilgilerin sıhhati konusundaki tartışmalara girmek yerine din fenomenolojisi ve antropolojiden faydalanması önemlidir. Tanyu, Alıcı'nın ifadesiyle “yerel antropolojik değerleri merkeze alan kültürel fenomenolojik" çalışmalar yapmıştır. Onun çalışmalarında etnografik-antropolojik veriler oldukça yoğun ve uyumlu şekilde bir araya getirilmiştir. ${ }^{66}$

Anadolu coğrafyasının zengin kültürel birikimi içinde din olgusu oldukça önemli bir konumda bulunmaktadır. Tanyu, bu çeşitliliğin izini sürmüş ve bunu da etnolojiyi kullanarak yapmıştır. Etnolojinin veri elde etme yöntemi doğrudan alandaki kültürel olguların tespiti ile bunların sistematik bir şekilde kayıt altına alınmasıdır. Bu bakımdan etnografik alan araştırmalarının dinler tarihi için kullanılması dini olguların geçmişten mevcut zamana kadar geçirmiş oldukları değişimi görmek bakımından önemlidir. Münir Yıldırım, Tanyu'nun metodolojisinin ana unsurlarını "tarihsel fenomenolojik metot" olarak tanımlamaktadır. ${ }^{67}$ Ona göre fenomenolojik yöntemin din bilimlerindeki önemli temsilcisi konumundaki Van der Leeuw, özellikle tarihi görmezden gelme eğilimindeyken, Hikmet Tanyu çalışmalarında tarihi dışlamadan dini fenomenlerin tarihin içinde var olduklarını kabul ederek araştırma yapmıştır.

Bilimler Enstitüsü Dergisi 1/5 (1994); Mustafa Alıc1, "Dinler Tarihi'ne Modern Türk Katkısı: Hikmet Tanyu (19181992)'nun Etnografik Fenomenolojisinin Temelleri", Din̂̂ Araştırmalar 9/26 (2006).

65 Mehmet Aydın, "Türklerin Dînî Tarihi Üzerinde Bir Değerlendirme", Türkiyat Araştırmaları Dergisi 4 (1997), 1.

${ }_{66}$ Mustafa Alıcı, Din Bilimlerinde Klasik ve Çağdaş Yaklaşımlar (İstanbul: Rağbet Yayınları, 2017), 335.

67 Yıldırım, "Hikmet Tanyu Örneği". 
Tanyu, Türklerde Taşla İlgili İnançlar isimli eserinde, fenomonolojisini neden etnografik bilgi üzerine temellendirdiğini açıkça ifade etmektedir. Ona göre bugün anlamsız ve herhangi bir değer atfedilemeyecek olarak görülen hikâye, masal, efsane ve çeşitli mitolojik kurgular ortaya çıktıkları toplumlar açısından değerlidirler. Dönemin tüm kültürel aktarımı bu olgular üzerinden bilindiğinden bunlara yaklaşımımız anlam ve değerlerini bilmemizi gerektirir. ${ }^{68}$

Çalışmalarında antropolojinin oldukça görünür olması, Tanyu'nun bilim anlayışının bir gereği olarak düşünülmelidir. Hocası Schimmel'in kutsal anlayışı, Tanyu'nun da çalışmalarında kutsalı alan araştırmaları aracılığıyla fenomenolojik yöntemin uygulanmasını gerekli kılmıştır. Etnografya sadece bilgi toplamak, ilişkiler kurmak, görüşmeler yapmak, metinleri kopyalamak ya da gözlemlerde bulunmanın ötesinde yoğun betimleme yapmayı da gerektirir. Geertz bu durumu "entelektüel çaba" olarak tanımlamaktadır. ${ }^{69}$ Tanyu için bu çaba belli bir yerle sınırlı kalmanın ötesinde, çok farklı coğrafyalarda, bilgi birikiminin ve kültürel olguların göründüğü mekânları dolaşmak, analiz etmek ve onları duyumsamakla mümkün olmuştur. Örneğin dönemin önemli simalarından tarihçi Zeki Velidi Togan (1890-1972) ile çalışmış ve tarih bilimine dair önemli bilgiler edinmişti. Tanyu, Almanca ve İngilizce gibi batı dillerini bilmesinden dolayı Togan tarafından dinler tarihine yönlendirilmiştir. ${ }^{70}$ 1971-1972 yılları arasında Avrupa'yı kapsayan gezilerde çok fazla temaslarda bulunmuş, müzelerde araştırmalar yapmış ve verimli bilimsel çalışmalar gerçekleştirmiştir. Aynı zamanda 1979 yılında Sovyet Rusya'ya yaptığı gezide Azerbaycan, Özbekistan ve Rusya'yı gezmiş, bu bölgedeki Türklerin dini, coğrafi, sosyo-kültürel yaşamlarına tanıklık etmiş ve verimli alan tecrübeleri edinmiştir. Bu geziler onda Türk kültürü hakkındaki hassasiyetinin oluşmasına imkân sağlamıştır. Geniş bir alana yayılan Türk kültür tarihinin takip edilmesi ve akademik alanda yapılan çalışmaların kapsamı Tanyu'nun bu konuya verdiği önemi göstermektedir. ${ }^{71}$ Özellikle Türklerin din ve kültür tarihine ilişkin akademik yetkinlik kazanan öğrencileri ve o kuşağın yetiştirmiş olduğu günümüz dinler tarihçileri hâlâ bu konuda çalışmalar yapmaya devam etmektedirler.

Tanyu, Anadolu coğrafyasının kültürel anlamdaki çeşitliliğinin farkında olan bir bilim insanıdır. 11. yüzyıldan itibaren başlayan Türk göçleri neticesinde başta Anadolu olmak üzere

68 Hikmet Tanyu, Türklerde Taşla İlgili İnançlar (Ankara: Ankara Üniversitesi Basımevi, 1968), 4.

69 Clifford Geertz, Kültürün Yorumlanması, çev. Hakan Gür (Ankara: Dost Kitabevi Yayınları, 1999), 19-20.

70 Alıc1, Din Bilimlerinde Klasik ve Çă̆daş Yaklaşımlar, 235.

71 Alıc1, "Dinler Tarihi'ne Modern Türk Katkısı: Hikmet Tanyu (1918-1992)'nun Etnografik Fenomenolojisinin Temelleri", 125. 
yakın coğrafyalarda İslam kültürü ile ilgili yoğun kültürel bir birikim oluşmuştur. İmar alanındaki gelişmeler, İslam dini hakkında yazılan eserler, sosyo-kültürel yaşamın yüzyıllardır sağlam bir gelenek oluşturması Tanyu açısından oldukça önemsenmiştir. Bu bakımdan, bu çeşitliliğin sadece dinler tarihinin araştırma yöntem ve teknikleriyle anlaşılması mümkün gözükmemektedir. Bunun yanında din fenomenolojisi ve din sosyolojisi bakımından da zengin kaynaklar söz konusudur. Anadolu'daki zengin dini çeşitlilik Hikmet Tanyu'ya göre şehir şehir gezilerek incelenmelidir. Tanyu'nun arkeolojik kalıntıları önemli birer unsur görüp bunların incelenmesiyle dinler tarihi alanında yapılacak çalışmaların kalitesinin artacağını dile getirmesiyle dinler tarihi bakış açısındaki nesnellik ortaya çıkmaktadır. ${ }^{22}$

Cumhuriyet dönemi kültür birikiminin önemli bir bölümü eski Anadolu medeniyetlerinin kültürel geçmişlerinin araştırılmasıyla elde edildiğinden Tanyu da bu bilgi birikiminin farkında olarak çalışmalar yapmış ve çalışmalarında kaynak kullandığı eserleri zikretmektedir. Dönemin etnoloji alanında önemli çalışmalar yapan Abdulkadir İnan, Ali Rıza Yalgın, Hamit Z. Koşay, Halit Bayrı, Orhan Acıpayamlı, Sedat Veysi Örnek, Nermin Erdentuğ gibi dönemin etnologlarının derleme ve çalışmalarından bahsetmektedir. ${ }^{73}$

Tanyu'nun hocası Schimmel'in Anadolu uygarlıklarının farklı bilim dallarının yardımıyla araştııılması gerektiğine vurgu yapması, onu çok alanlı (multidisipliner) bir anlayışla çalışan ve konuya yaklaşımı bakımından günümüzde de çalışmaları ilgi gören bir akademisyen yapmıştır. Tanyu mevcut materyallerin sadece dinler tarihi açısından değerlendirilmesinin, materyalin gerçek değerinin ve öneminin kavranamayacağını düşünmektedir. Bu bakımdan onun yöntemi hem tarihten hem de fenomenolojiden beslenen bir yöntemdir. Alıcı, Tanyu'nun odaklandığı konuları iki başlıkta incelemektedir. Birincisi Tanyu'nun Türk tarihi, kültürü ve kadim inançlarıyla, filoloji, etnografya gibi alanlarda yoğunlaştı̆̆ı çalışmaları; ikincisi ise Tanyu'nun genel dinler tarihini konu edindiği çalışmalarıdır. Tanyu genel din çalışmalarında bile etnografik çalışma prensibini elden bırakmamış, çalışmalarını etnografyanın yöntem ve araştırma ilkelerini göz önünde bulundurarak yapmıştır. Buradaki temel amaç çalışılan konuların İslam, Yahudilik,

72 Hikmet Tanyu, Dinler Tarihi Araştırmaları (Ankara: Ankara Üniversitesi Basımevi, 1973), 123.

73 Tanyu, Dinler Tarihi Araştırmaları, 124-125. Tanyu, Türklerde Taşla İlgili İnançlar, 102. 
Hristiyanlık ve diğer dini gruplarla olan kültürel bağların ortaya konulması ve kültürel etkileşimlerin mümkün oldukça anlaşılmasının sağlanmasıdır. ${ }^{74}$

Tanyu'nun fenomenolojik çalışmalarındaki pratik çerçeve, çoğunlukla etnografik veriler aracılığıyla yapılan değerlendirmelerden oluşmaktadır. Bu bakımdan Tanyu'nun pratik temeli Türk Dini Tarihindeki halk inançlarındaki dini fenomenleri tespiti ile başlamaktadır. Türk halk kültüründeki etnolojik ve folklorik fenomenlerin ne anlama geldiğini açıklamaya çalışan Tanyu'ya göre bu fenomenlerin gerçekten anlaşılabilmesi için özlerine inilmesi ve gerçek anlamlarının anlaşılması gerekir. Ona göre bu süreçte fenomenlerin tarihi süreçteki boyutunun da göz ardı edilmemesi önemlidir. Türk inançlarındaki fenomenler Tanyu tarafından dini olarak kabul edilmekte ve bundan dolayı da bunların dini değerlerinin anlaşılmasına büyük önem verilmektedir. Yıldırım'ın da işaret ettiği gibi Tanyu her ne kadar dil bilimden çokça faydalansa da özellikle kültürel çalışmalarda etnografik filolojiyi metodolojik bir araç olarak kullanmıştır. Çünkü kültürün önemli bir unsuru haline gelen adak, taş, dağ, ateş gibi fenomenleri çok fazla öne çıkarmaktadır. Bu bakımdan Tanyu'nun fenomenolojisi tarihsel ve milli unsurları önemsemesiyle kültürel değerlerin oldukça görünür hale geldiği bir disiplindir. ${ }^{75}$

Hikmet Tanyu, Türklerin Dini Tarihçesi adlı eserinde etnografik bilgilerin ışı̆̆ında Türklerin dini yaşamına ilişkin çok sayıda yanlış anlatıma ve betimlemeye cevap vermektedir. Benimsediği metodoloji, sadece tasvir etmekle sınırlı olmayan aynı zamanda etnografik bilgi ile yapılan ritüelin anlamının ortaya konmasına dayanmaktadır. Bu şekilde tarihsel bilgiler 1şığında başka coğrafyalarda benzer uygulamaların ne anlama geldiğini de örnek vererek söz konusu anlatımların gerçek dışılığını ortaya koymaktadır. Buna göre yukarıda da ifade edildiği gibi Türklerin “Gök Tengri” dini, “Gök Tanrı” olarak bildiğimiz, yüce bir kuvvetin varlığını kabul eden bir inançtır. ${ }^{76}$ En eski Türkçe kaynak olarak kabul edilen Orhun yazıtlarındaki şekliyle Tanrı sözcügü Tenri/Tengri olarak geçmektedir ve bu kavram tüm Türkçe lehçelerde az bir değişimle aynen muhafaza edilmiş ve kullanılmıştır. Bununla birlikte, Tanrı sözcügünün kadim Anadolu uygarlıklarından Orta Asya derinliklerine kadarki serüveni Tanyu tarafından ifade edilmiştir. Burada özellikle yabancı kaynaklarda kullanılan anlamların Tanyu tarafından etnografik bilgi verilerek yanlışlandığı da görülmektedir. Buna

\footnotetext{
74 Alıcı, "Dinler Tarihi'ne Modern Türk Katkısı: Hikmet Tanyu (1918-1992)'nun Etnografik Fenomenolojisinin Temelleri", 126-127.

75 Yildırım, "Hikmet Tanyu Örneği", 66.

76 Hikmet Tanyu, Türklerin Dini Tarihçesi (İstanbul: Türk Kültür Yayını, 1978), 30.
} 
göre Anadolu'da Hitit ve Sümer döneminde mabetlerin yapılması, bu uygarlıkların yerleşik hayata geçişlerine bağlanırken, Türklerin göçebe bir toplum olmasından ötürü mabet olgusuna rastlanılmadığ 1 yönündeki tespite katılmamakta ve Türklerin yerleşik düzeninden ve mabet uygulamalarından örnekler vermektedir. Tanyu, zamanla Türklerin hayat koşullarında meydana gelen değişime paralel olarak Tanrı adı ve mabet yapısında birtakım değişimlerin kaçınılmaz olduğunu dile getirmektedir. Burada toplumsal yapının değişimi ve buna bağlı olarak din olgusunda da değişimlerin olduğu görülmektedir.77

Tanyu'nun bilim anlayışı göz önüne alındığında, Alıcı'nın da ifade ettiği gibi teolojik ön kabullerin dinler tarihi için yeterli olmadığı, bu alanda yapılan çalışmaların teolojik ön kabulden ziyade antropolojik olmasının zorunluluğu belirmektedir. Dinler tarihçilerinin dinler tarihi araştırmaları yaparken geniş anlamda etnolojiye, özel anlamda da etnografyaya başvurmalarının temel sebebi, dindar insan eyleminin ve karşılıklı ilişkilerinin, inanç ve inanç sistemlerinin, bilgi alanının, mensubu bulunduğu cemaatin, kutsal kabul ettiği manevi nitelikli fenomenlerin yorumlanması ve anlaşılmasıdır. ${ }^{78}$ Geertz, din için "asla yalnızca metafizik değildir" demektedir.79 Bunun anlamı, din mensubu olan herkesin ritüelleri, araçları, nesneleri derin ahlaksal bir ciddiyet içinde etrafa yayılır. Kişi ve topluluk için derin bir anlam taşıyan inanma eylemi duygusal bir bağlılık gerektirir ve bunun anlaşılması zaman alır. Bu bakımdan antropoloji, tarihsel anlam, mistik iç dünya, formülleştirilen sembollerle bu bağlılık hissini anlamaya çalışır.

Tanyu'nun bir din antropoloğu olarak anılmasının kayda değer bir diğer göstergesi, Ziya Gökalp'in Emile Durkheim'dan ödünç aldığı ve bu yönde çokça eleştirilmesine neden olan Türklerin ilk dininin totemizm olduğu yönündeki teoriyi ayrıntılı bir şekilde analiz etmesidir. Antropologlar tarafından oldukça kullanışlı bir alan olan etnografik araştırmaların sonuçlarını değerlendirirken başvurdukları totem, totemizm ve tabu kavramlarının gerçekten ne için kullanıldığı Tanyu tarafından oldukça ayrıntılı bir şekilde tarif edilmiştir. Bu çalışmasında Tanyu'nun antropoloji literatürüne oldukça hâkim olduğu görülmektedir. Hemen hemen o dönem bu kavramlar üzerine antropolojik çalışma yapan çoğu antropoloğun görüşlerinden faydalanmıştır. Tanyu, kavramların sadece fenomenolojik yönleriyle ilgilenmemekte, aynı zamanda etnografik açıdan yoğun tasvirlerle anlamın bilgisini de

\footnotetext{
77 Hikmet Tanyu, İslamlıktan Önce Türklerde Tek Tanrı İnancı (Ankara: Ankar Üniversitesi Basımevi, 1980), 7, 16.

$78 \mathrm{Alıc1}$, Din Bilimlerinde Klasik ve Çağdaş Yaklaşımlar, 242-243.

79 Geertz, Kültürün Yorumlanması, 152.
} 
vermeye çalışmıştır. Totemi benimseyenlerin içinde bulundukları kültürel ortamı görelilik ilkesi gereği tam anlamıyla bilimsel bir üslupla aktarmayı başarabilmiştir. ${ }^{80}$

Hikmet Tanyu'nun sürdürdüğü bilim anlayışı, Türklerin dini tarihine yönelik araştırılmaların Anadolu coğrafyası ile sınırlı kalmamasını sağlamıştır. Bu çabalar Türklerin gerek yaşamakta olduğu gerekse de daha önce izlerinin görüldüğü coğrafyalarda araştırma yapılmasının önünü açmıştır. Bu çalışma yöntemi, bilimsel hassasiyet gerektirdiği kadar milli bir sorumluluk olarak da algılanmıştır. Böylece Cumhuriyetin kurucu değerlerinin diğer alanlarda olduğu gibi dinler tarihi çalışan bilim insanlarınca da devam ettirildiği anlaşılmaktadır. Dolayısıyla Tanyu' dan sonra da devam ettirilen dinler tarihçiliği bu anlayışın üzerine inşa edilmiştir. Günümüz dinler tarihi çalışmalarında bir alan olarak Türk Dini Tarihi çalışmaları Tanyu Ekolü olarak ortaya çıkan bu bilim anlayışının neticesinde elde edilen verilerle güçlü bir hafıza meydana gelmiştir. Özellikle Orta Asya coğrafyasında değişen demografik yapı göz önüne alındığında Türklerle ilgili yapılan çalışmaların kayıt oluşturması ve kültürel izlerin takip edilmesi açısından bu çalışmalar büyük öneme sahiptir.

Hikmet Tanyu'ya kadarki süreçte dinler tarihinin kurumsal bir kimlik edinmediği, sadece belli dönemlerde gerek yurt dışından gerekse yurt içinden konuya ilgi duyan ya da bu konuda belli bir zaman diliminde çalışmış kişiler ders vererek bu alandaki eksikliğin giderildiği görülmektedir. Hikmet Tanyu tam anlamıyla dinler tarihinin bir kimlik edinmesinde ve akademik bir uğraş olarak sonraki nesillere aktarılmasında önemli bir konumdadır. Çalışmalarına Türk kültürü ve dini üzerine yoğunlaşarak başlamış, dini alanda yapılan tüm gayretleri aynı zamanda kültürel alandaki hassasiyeti sayesinde meydana gelmiş, bunu da çalışmalarında izah etmiştir. Bu bakımdan Tanyu'nun çalışmaları tam anlamıyla din antropolojisi açısından önem taşımakta ve günümüzde bile bu alanda temel başvuru kaynağ1 olarak değerini korumaktadır. Dolayısıyla Hikmet Tanyu'yu din antropoloğu olarak tanımlamak yerinde olacaktır. Çünkü Tanyu, bir toplumun kültürünün önemli bir belirleyicisi olan sosyal normların anlaşılmadan dini kültürünün anlaşılamayacağını ifade etmektedir. Tanyu, dini fenomenleri incelerken fenomenolojik ve tarihsel yönteme başvurmuş, aynı zamanda etnografik bilgiyi de göz ardı etmemiştir.

\footnotetext{
80 Hikmet Tanyu, "Totem, Totemizm ve Tabu Üzerinde Yeni Araştırmalar", Ankara Üniversitesi İlahiyat Fakültesi
} Dergisi 26/1 (1984). 


\section{Sonuç}

Cumhuriyet döneminde, Türklerin dinî tarihi ve kültürü gerek dinler tarihi alanında gerekse bu alan dışında çalışma yapanlar tarafından çok fazla ilgi görmüştür. Özellikle Türklerin Müslüman olmadan önceki dinî yaşantıları merkeze alınarak birtakım arayışlara gidilmiş ve bu konuda bazı farklı yorumlar dile getirilmiştir. Anadolu coğrafyasında yoğun antropolojik ve arkeolojik çalışmalar yapılmış, geçmişle bağ kurulması hedeflenmiş, dinler tarihi çalışmaları da bu kapsamada kimi zaman ulus inşası fikrine paralel ilerlemiştir.

Ülkemizde Georges Dumézil ile başlayan dinler tarihçiliği kısmen dönemin uluslaşma politikalarının gölgesinde ilerlemiş ve bu doğrultuda söylemler geliştirilmiştir. Devamında Annemarie Schimmel İslami anlayışın daha görünür olduğu bir sürece girilmiştir. Böylece Türkiye'nin ilk dinler tarihi doktoru olarak Hikmet Tanyu'nun kutsal anlayışını Türk dinine uygulamasının yolu açılmıştır. Bu bakımdan Tanyu, Türk dinine yönelik yaptığı fenomenolojik çalışmaları Cumhuriyet döneminin bir zihinsel mirası olarak aktarılan uluslaşma aracılığıyla milli kimlik inşasında çalışmalarıyla katkı sağlamıştır. Tanyu mevcut kültürün geçmişle olan bağlantısını göz ardı etmeyerek İslam ve onunla bütünleştiği milli hisler ile ortaya çıan, yüksek aidiyet gerektiren bir dinler tarihçiliği yöntemi inşa etmiştir. Tanyu'nun etnografik fenomenolojik yöntemi günümüzde Türk dini konusundaki çalışmalara yol göstermeye devam etmektedir. Bu bakımdan dönemin koşullarında millileşme ve İslamileşmenin yeniden görünür olduğu bir toplumsal alanda Türk Dinî Tarihi konusunda yapılan yoğun çalışmaların merkezinde etnografyanın kullanıldı̆̆ı görülmektedir. Hikmet Tanyu'nun etnografik fenomenolojiyi iyi bir şekilde kullanması, dinler tarihçiliğimiz açısından son derece verimli olmuştur. 


\section{Kaynakça}

Adam, Baki. "Annemarie Schimmel'den Prof. Dr. Abdurrahman Küçük'e Ankara İlahiyat'ın Türkiye'deki Dinler Tarihi Çalışmalarına Katkısı". Türkiye'de Dinler Tarihi'nin Kurumsallaşması Sürecinde Prof. Dr. Abdurrahman Küçük. ed. Ahmet Hikmet Eroğlu. 135154. Ankara: Berikan Yayınevi, 2016.

Ahmad, Feroz. Modern Türkiye'nin Oluşumu. çev. Yavuz Alogan. İstanbul: Sarmal Yayınevi, 1994.

Akçura, Yusuf. Üç Tarz-ı Siyaset. Ankara: Türk Tarih Kurumu Basımevi, 1976.

Akyüz, Yahya. Türk Ĕ̆itim Tarihi. İstanbul: Pegem Akedemi, 19. Basım, 2011.

Alıc1, Mustafa. "Dinler Tarihi'ne Modern Türk Katkısı: Hikmet Tanyu (1918-1992)'nun Etnografik Fenomenolojisinin Temelleri". Dinî Araştırmalar 9/26 (2006), 123-154.

Alıcı, Mustafa. Din Bilimlerinde Klasik ve Çağdaş Yaklaşımlar. İstanbul: Rağbet Yayınları, 2017.

Arkoun, Mohammed. "İslâmi Bir Bakış Açısı İçinde Pozitivizm ve Gelenek, Kemalizm Olayı". Cogito 1 (1994), 51-65.

Atasağun, Galip. "Türkiye'de Dinler Tarihi Çalışmaları". Necmettin Erbakan Üniversitesi İlahiyat Fakültesi Dergisi 20/20 (2005), 203-248.

Aydın, Fuat-Aydın, Feyza Betül. Georges Dumézil'den Dinler Tarihi Dersleri. Ankara: Eski Yeni Yayınları, 2012.

Aydın, Mahmut. Anahatlarıla Dinler Tarihi. Samsun: Ensar Neşriyat, 2013.

Aydın, Mehmet. "Türklerin Dînî Tarihi Üzerinde Bir Değerlendirme". Türkiyat Araştırmaları Dergisi 4 (1997), 1-9.

Aydın, Suavi. Antropoloji Sözlüğ̈̈̈. ed. Kudret Emiroğlu-Suavi Aydın. Ankara: Bilim ve Sanat Yayınlar1, 2003.

Ayhan, Halis. Türkiye'de Din Eğitimi. İstanbul: DEM Yayınları, 2004.

Berkes, Niyazi. Türkiye'de Çă̆daşlaşma. İstanbul: Yapı Kredi Yayınları, 2016.

Budda, Hilmi Ömer. Dinler Tarihi. İstanbul: Vakit, 1935.

Budda, Hilmi Ömer. Kurban ve Tufan Üzerine Makaleler. çev. Bekir Zakir Çoban. İstanbul: İnsan Yayınları, 2003.

Cündioğlu, Dücane. Türkçe Kur'an ve Cumhuriyet İdeolojisi. İstanbul: Kitabevi, 2. Basım, 1998.

Demir, Remzi-Atılgan, Doğan. Dil ve Tarih-Coğrafya Fakültesi ve Türkiye'de Beşeri Bilimlerin Yeniden İnşaası. Ankara: Ankara Üniversitesi Basımevi, 2008.

Doğan, Atila. Osmanlı Aydınları ve Sosyal Darwinizm. İstanbul: İstanbul Bilgi Üniversitesi Yayınları, 2006.

Doğrul, Ömer Rıza. Yeryüzündeki Dinler Tarihi. İstanbul: Inkılâp Kitabevi, 1947.

Dumézil, Georges. "Georges Dumézil'in Gizli Şölenleri". Tarih ve Toplum 42 (1987), 52-56.

Dumézil, Georges. Kafkas Halkları Mitolojisi. çev. Musa Yaşar Sağlam. Ankara: Ayraç Yayınları, 2000.

Dumézil, Georges. Mit ve Destan I: Hint-Avrupa Halklarının Destanlarında Üç Iş̧lev İdeolojisi. çev. Ali Berktay. İstanbul: Yapı Kredi Yayınları, 2012.

Ekşigil, Adnan. "Georges Dumézil". Tarih ve Toplum 42 (1987), 49-52.

Eliade, Mircea. Dinler Tarihi: İnançlar ve İbadetlerin Morfolojisi. çev. Mustafa Ünal. Konya: Serhat Kitabevi, 2005.

Ergin, Osman. Türk Maarif Tarihi 1-2. İstanbul: Eser Matbaası, 1977.

Geertz, Clifford. Kültürün Yorumlanması. çev. Hakan Gür. Ankara: Dost Kitabevi Yayınları, 1999.

Georgeon, François. Türk Milliyetçiliğinin Kökenleri Yusuf Akçura (1876-1935). çev. Alev Er. İstanbul: Tarih Vakfı Yurt Yayınları, 2005. 
Gökalp, Ziya. Türkçülü̈̆̈̈̈n Esasları. İstanbul: Varlık Yayınları, 8. Basım, 1969.

Gökbel, Ahmet. "M. Şemseddin (Günaltay) ve Dinler Tarihine Yaptığı Katkılar". Fırat Üniversitesi İlahiyat Fakültesi Dergisi 5 (2000), 33-44.

Günaltay, M. Şemseddin. Dinler Tarihi: Yeryüzündeki Illkel Dinler. İstanbul: Kesit Yayınları, 2006.

Günaltay, M. Şemseddin. İslam Öncesi Araplar ve Dinleri. Ankara: Ankara Okulu Yayınları, 2013.

Güngör, Ali İsra. "The Turkish Contribution to the History of Religions". Numen 54/1 (2007), 71-92.

Güngör, Erol. Kültür Değişmesi ve Milliyetçilik. İstanbul: Ötüken Neşriyat, 14. Basım, 2006.

İnan, Afet. Türkiye Halkının Antropolojik Karakteri ve Türkiye Tarihi. Ankara: Türk Tarih Kurumu Basımevi, 1947.

İnan, Afet. Atatürk Hakkında Hatıralar ve Belgeler. ed. Arı İnan, İstanbul: Türkiye İş Bankası Kültür Yayınları, 8. Basım, 2009.

Jaschke, Gotthard. Yeni Türkiye'de İslamlık. çev. Hayrullah Örs. Ankara: Bilgi Yayınevi, 1972.

Kafesoğlu, İbrahim. Türk Milliyetçiliğinin Meseleleri. İstanbul: Milli Eğitim Basımevi, 1970.

Kalın, Fethullah. Rudolf Otto'da Din, Kutsallık ve Mistik Tecrübe. İstanbul: Ötüken Neşriyat, 2014.

Kansu, Şevket Aziz. Türk Antropoloji Enstitüsü Tarihçesi. İstanbul: Maarif Matbaası, 1940.

Karpat, Kemal H. İslâm'ın Siyasallaşması. Osmanlı Devleti'nin Son Döneminde Kimlik, Devlet, İnanç ve Cemaatin Yeniden Yapılandırılması. çev. Şiar Yalçın. İstanbul: Timaş Yayınları, 2013.

Kurt, Hakan. Türk Antropoloji Macmuası Transkripsiyonu 1925-1928. Ankara: Gece Kitaplığı, 2017.

Kushner, David. Türk Milliyetçiliğinin Doğuşu (1876-1908). çev. Şevket Serdar Türet vd. İstanbul: Kervan Yayınları, 1979.

Küçük, Abdurrahman. "Tanzimattan Günümüze Türkiye'de Dinler Tarihi". Türkiye'de Dinler Tarihi (Dünü, Bugünü ve Geleceği). ed. Ali İsra Güngör vd. 333-364. Ankara: Türkiye Dinler Tarihi Derneği Yayınları, 2010.

Maksudyan, Nazan. Türklüğ̈̈̈ Ölçmek. İstanbul: Metis Yayınları, 2007.

Sami, Şemseddin. Esatir: Dünya Mitolojisinden Örnekler. çev. Cengiz Batuk. İstanbul: İnsan Yayınları, 2007.

Sivrioğlu, Ulaş Töre. Tek Parti Döneminde Orta Asya ve Sümer-Hitit Araştırmaları. Celal Bayar Üniversitesi Sosyal Bilimler Enstitüsü, Tarih Anabilim Dalı, Yayımlanmamış Doktora Tezi, 2010.

Su, Süreyya. Hurafeler ve Mitler: Halk İslâmında Senkretizm. İstanbul: İletişim Yayınları., 2011.

Şenoğlu, Kemal. Mayatepek Raporları: Türk Tarih Tezi ve Mu Kıtası. İstanbul: Kaynak Yayınları, 2006.

Tanyu, Hikmet. Türklerde Taşla İlgili İnançlar. Ankara: Ankara Üniversitesi Basımevi, 1968.

Tanyu, Hikmet. Dinler Tarihi Araştırmaları. Ankara: Ankara Üniversitesi Basımevi, 1973.

Tanyu, Hikmet. Türklerin Dini Tarihçesi. İstanbul: Türk Kültür Yayını, 1978.

Tanyu, Hikmet. İslamlıktan Önce Türklerde Tek Tanrı Inancı. Ankara: Ankar Üniversitesi Basımevi, 1980.

Tanyu, Hikmet. "Totem, Totemizm ve Tabu Üzerinde Yeni Araştırmalar". Ankara Üniversitesi İlahiyat Fakültesi Dergisi 26/1 (1984), 155-172.

Tezcan, Mahmut. Türk Aile Antropolojisi. Ankara: İmge Kitabevi, 2000.

Toprak, Zafer. Darwin'den Dersim'e Cumhuriyet ve Antropoloji. İstanbul: Doğan Kitap, 2015.

Tümer, Günay. "Hocamız Hikmet Tanyu". Erciyes Üniversitesi Sosyal Bilimler Enstitüsü Dergisi 1/5 (1994), 5-10. 
Türk Dil Kurumu. Türkçe Sözlük. Ankara: Türk Dil Kurumu Yayınları, 10. Baskı, 2005.

Ünal, Mustafa. Din Fenomenolojisi: Tarihçe, Yöntem ve Uygulama. Kayseri: Geçit Yayınları, 1999.

Vassaf, Gündüz (ed.). Belkıs Halim Vassaf'ın Defterinden Dumézil'in Sosyoloji Ders Notları. İstanbul: Boğaziçi Üiversitesi Yayınevi, 2009.

Yıldırım, Münir. "Türk Dini Tarihi Araştırmalarında Fenomenolojik Metod: Hikmet Tanyu Örneği". Türkiye'de Dinler Tarihi (Dünü, Bugünü ve Geleceği). ed. Ali İsra Güngör vd. 6372. Ankara: Türkiye Dinler Tarihi Derneği Yayınları, 2010.

Yörükân, Yusuf Ziya. Müslümanlıktan Evvel Türk Dinleri: Şamanizm. İstanbul: Ötüken Neşriyat, 2006. 